Article

\title{
Cytokine Effects on the Entry of Filovirus Envelope Pseudotyped Virus-Like Particles into Primary Human Macrophages
}

\author{
Tzanko S. Stantchev ${ }^{1, *}$, Autumn Zack-Taylor ${ }^{1}$, Nicholas Mattson ${ }^{1}$, Klaus Strebel ${ }^{2}$, \\ Christopher C. Broder ${ }^{3}$ and Kathleen A. Clouse ${ }^{1, *}$ \\ 1 Division of Biotechnology Review and Research 1 (DBRR1), Office of Biotechnology Products (OBP), \\ Center for Drug Evaluation and Research (CDER), US Food and Drug Administration (FDA), Silver Spring, \\ MD 20993, USA; autumn.zack-taylor@fda.hhs.gov (A.Z.-T.); nicholas.mattson@fda.hhs.gov (N.M.) \\ 2 Laboratory of Molecular Microbiology, National Institute of Allergy and Infectious Diseases (NIAID), \\ National Institutes of Health (NIH), Bethesda, MD 20814, USA; kstrebel@niaid.nih.gov \\ 3 Department of Microbiology and Immunology, Uniformed Services University of the Health \\ Sciences (USUHS), Bethesda, MD 20814,USA; christopher.broder@usuhs.edu \\ * Correspondence: tzanko.stantchev@fda.hhs.gov (T.S.S.); kathleen.clouse@fda.hhs.gov (K.A.C.)
}

Received: 17 July 2019; Accepted: 18 September 2019; Published: 23 September 2019

\begin{abstract}
Macrophages are one of the first and also a major site of filovirus replication and, in addition, are a source of multiple cytokines, presumed to play a critical role in the pathogenesis of the viral infection. Some of these cytokines are known to induce macrophage phenotypic changes in vitro, but how macrophage polarization may affect the cell susceptibility to filovirus entry remains largely unstudied. We generated different macrophage subsets using cytokine pre-treatment and subsequently tested their ability to fuse with beta-lactamase containing virus-like particles (VLP), pseudotyped with the surface glycoprotein of Ebola virus (EBOV) or the glycoproteins of other clinically relevant filovirus species. We found that pre-incubation of primary human monocyte-derived macrophages (MDM) with interleukin-10 (IL-10) significantly enhanced filovirus entry into cells obtained from multiple healthy donors, and the IL-10 effect was preserved in the presence of pro-inflammatory cytokines found to be elevated during EBOV disease. In contrast, fusion of IL-10-treated macrophages with influenza hemagglutinin/neuraminidase pseudotyped VLPs was unchanged or slightly reduced. Importantly, our in vitro data showing enhanced virus entry are consistent with the correlation established between elevated serum IL-10 and increased mortality in filovirus infected patients and also reveal a novel mechanism that may account for the IL-10-mediated increase in filovirus pathogenicity.
\end{abstract}

Keywords: Ebola virus (EBOV); filoviruses; cytokines; interleukin-10 (IL-10)

\section{Introduction}

Filoviruses, particularly members of the Ebola and Marburg genera, cause severe disease with one of the highest mortality rates observed among human pathogens. Increased levels of a variety of cytokines/chemokines, presumed to be an integral part of virus pathogenesis, have been established in patients infected with strains of the Zaire [1-9], Sudan [10] and/or Bundibugyo [11] ebolavirus species.

It was demonstrated in vitro that not only ebolavirus infection [12-15], but also ebolavirus surface glycoprotein(s) (GP), presented as either soluble molecules or on the surface of replication incompetent virus-like particles or inactivated virions [14,16-26], and as ebolavirus GP derived peptides [12,18,26-28], are capable of inducing cytokine expression in challenged cells. Several cell surface molecules have been implicated in the EBOV GP-induced cytokine secretion (including IL-10), Tim-1 [29], TLR-4 [30,31] and/or LSECtin (CLEC4G)/DAP12 [18]. The role of Tim-1 and TLR-4 was demonstrated 
using a transgenic mouse model, while the effect(s) of LSECtin/DAP12 were established in human monocyte-derived dendritic cells.

Despite species to species, strain to strain and study to study variability, the EBOV and Sudan virus (SUDV) strains were generally found to induce a variety of pro-inflammatory cytokines (IL-1 $\beta$, IL-6, IL-8, MCP-1, MIP-1 $\alpha$, MIP-1 $\beta$, etc.,) both in vivo and in vitro. Some [1-3,9], but not all $[6,8]$, studies reported significantly increased TNF- $\alpha$ levels in samples from EBOV infected patients. TNF- $\alpha$ was not increased in the serum samples of patients infected with SUDV, although several other pro-inflammatory cytokines (IL-6, IL-8, IP-10, MIP-1 $\beta$ [10], IL-1 $\alpha$, IL-6, IP-10, MCP-1, MIP-1 $\alpha$ [32]) were elevated in non-survivors. From pro-inflammatory cytokines/chemokines, only MCP-1 serum levels were increased in Bundibugyo virus (BDBV)- infected individuals [11] and peripheral blood mononuclear cells (PBMC) infected with BDBV produced 2- to 10-fold lower levels of TNF- $\alpha$, MCP-1, IL-1 $\beta$ and MIP1- $\alpha$ compared to cells infected with EBOV strain Mayinga [13].

The role of pro-inflammatory cytokines in filovirus pathogenesis appears to be complex and may be time-dependent. Although higher levels of pro-inflammatory cytokines are generally associated with increased viral load and/or poor prognosis [1,7-9,32-36], there are also data suggesting that an early robust pro-inflammatory cytokine response may result in asymptomatic infection $[4,5]$ or improved survival [2].

Intriguingly, the anti-inflammatory cytokine IL-10 appears to be consistently elevated in patients infected with EBOV [1-3,8,9,33], SUDV [10] and BDBV [11], and has been associated with poor disease outcome.

IL-4 and IL-13, which may also be referred to as anti-inflammatory cytokines [37], have been less extensively studied in EBOV disease (EVD). Waquier; et al., [35] reported either similar or significantly lower IL-4 and/or IL-13 levels, compared to healthy controls, in samples obtained from surviving and non-surviving patients during the outbreaks in Gabon and the Republic of Congo, which occurred between 1996 and 2005. Increased IL-13 (days 7 and 8 of clinical illness), but undetectable IL-4 levels, were established in a healthcare care worker infected with the Makona strain during the 2014-2016 EBOV outbreak [6]. Transient elevations of IL-4 were detected in several Makona-infected patients during the course of disease but, in general, these increases were not considered statistically significant [8].

Macrophages are one of the major filovirus targets and serve both as sites of virus replication and sources of cytokine production (reviewed in $[6,25,38,39]$ ). However, there is a paucity of information as to how the altered cytokine levels in EVD may affect the susceptibility of uninfected macrophages to virus entry at the sites of filovirus replication. Currently, it is well established in vitro that macrophages may present as heterogeneous phenotypes, driven by certain cytokines. In brief, TNF- $\alpha$ is known to induce the classical activated M1 phenotype, while IL4 and/or IL-13 induce the alternatively activated M2a macrophages and IL-10 treatment is associated with cell polarization to the M2c phenotype (reviewed in [40-44]). In this study, we pre-incubated macrophages with these cytokines and tested their ability to support the entry of $\beta$-lactamase (BLaM)-containing virus-like particles (VLP), pseudotyped with different filovirus surface GPs. To mimic more closely the in vivo conditions, we also performed the same experiments using macrophages pre-incubated with a cocktail(s) of cytokines known to be elevated in EVD. Using macrophages from multiple healthy donors, we established that pre-incubation with IL-10, alone or in combination with pro-inflammatory cytokines, resulted in increased filovirus GP pseudotyped VLP entry, while having an opposite or no effect on the fusion of VLP pseudotyped with influenza hemagglutinin (HA)/neuraminidase (NA). Subsequently, by performing microarray and Flow cytometry analysis, we attempted to identify the IL-10 inducible factors potentially affecting the filovirus VLP entry into primary macrophages. 


\section{Materials and Methods}

\subsection{Reagents}

Recombinant cytokines were purchased from Peprotech (Rocky Hill, NJ, USA) and/or R\&D Systems (Minneapolis, MN, USA). The cytokines were re-suspended in $0.5 \%$ clinical grade human serum albumin (HSA) to a concentration of $20 \mathrm{mg} / \mathrm{mL}$ and used immediately or aliquoted and stored at $-80^{\circ} \mathrm{C}$. Dulbecco's Modified Eagle's Medium (DMEM), Penicillin/Streptomycin antibiotic solution, sodium pyruvate $(100 \mathrm{mM})$, Dulbecco's Phosphate Buffered Saline (DPBS) with or without $\mathrm{Ca}^{2+}$ and $\mathrm{Mg}^{2+}$, and L-glutamine (200 $\mathrm{mM}$ ) were obtained from Lonza (Walkersville, MD, USA). Phenol red-free DMEM and the CCF2/AM Beta lactamase Loading Kit (GeneBLAzer Reporter Assay) were purchased from Invitrogen/Thermo Fisher Scientific (Carlsbad, CA, USA). HEPES buffer solution (1 M) was purchased from Quality Biological (Gaithersburg, MD, USA). The nuclear fluorescent dye DRAQ5 $^{\mathrm{TM}}$ was obtained from BioStatus Shepshed, UK, or Thermo Fisher Scientific. The FuGENE 6 transfection reagent was purchased from Promega Corp. (Madison, WI, USA). Probenecid was obtained from Sigma-Aldrich (St. Louis, MO, USA), Enzo Life Sciences (Farmingdale, NY, USA) or Thermo Fisher Scientific (Waltham, MA, USA). HSA (25\% sterile solution) was purchased from CSL Behring (Kankakee, IL, USA). The pooled human serum was prepared in house from multiple serum aliquots, obtained at the NIH Department of Transfusion Medicine from healthy donors, seronegative for HIV-1, HIV-2, hepatitis B and hepatitis C.

Antibodies: The APC conjugated anti-CD206 (Clone 19.2), anti-IL21R (Clone 17A12) and anti-CD29/integrin $\beta 1$ (Clone MAR4) monoclonal antibodies (mAb), and the FITC labeled anti-CD61/integrin $\beta 3 \mathrm{mAb}$ were obtained from BD Pharmingen. The anti- CD163 PE labeled mAb (clone GHI/61), the anti-Niemann-Pick cholesterol transporter 1 (NPC1) (Clone 17B5) and anti-cathepsin $\mathrm{L}$ (Clone 33/1) mAb (unlabeled or FITC conjugated) were obtained from Invitrogen/Thermo Fisher Scientific. The anti-human CD51/integrin alpha V/CD51 (Clone P2W7) Alexa Fluor ${ }^{\circledR}$ 488-conjugated $\mathrm{mAb}$ was purchased from R\&D Systems

Plasmids: The plasmids VP40, VP40-BlaM and VP40-GFP were provided by Dr. Yoshihiro Kawaoka, Dr. Lijun Rong and Dr. Paul Bieniasz, respectively. The plasmids encoding the full length (VRC6001) and the $\Delta$-mucin form (VRC6002) of the Kikwit strain EBOV GP were provided by Dr. Gary Nabel. The plasmids encoding the full-length surface glycoproteins of EBOV strain Mayinga, Sudan virus (SUDV) strain Boniface, SUDV strain Gulu, Bundibugyo virus (BDBV), Tai Forest virus (TAFV), Reston virus (RESTV) and Marburg virus (MARV) strain Angola were provided by Dr. Andrea Marzi. The plasmid encoding the Makona strain EBOV GP (GeneBank: KX013101.1) was designed in our laboratory using the VectorBuilder (Cyagen) software and subsequently synthesized de novo by VectorBuilder. The RBR-Fc protein and/or the RBR-Fc expression plasmid were provided by Dr. Judith White. The RBR-Fc protein was expressed in 293T cells, purified by Protein A affinity chromatography and concentrated using Millipore $10 \mathrm{kDa}$ cut off pore size centrifugal filter units. The Vpr-BlaM encoding plasmid was provided by Dr. Mike Miller and the psPAX2 packaging plasmid was obtained from Addgene (Addgene plasmid 12260, a gift from Dr. Didier Trono). The influenza hemagglutinin (HA) [A/Vietnam 2004 (H5N1)] and neuraminidase (NA) [A/California 2009 (H1N1)] encoding pVRC/R plasmids were provided by Dr. Carol Weiss.

\subsection{Cells and Cell Culture Conditions}

The 293T cells were obtained from Dr. G. Quinnan (USUHS, Bethesda, MD) and maintained in DMEM supplemented with 10\% fetal calf serum (FCS), 2 mM L-glutamine, and antibiotics (DM-10) at $37^{\circ} \mathrm{C}$ in a humidified, 5\% CO2 atmosphere. Human peripheral blood mononuclear cells (PBMC) were isolated by Ficoll-Paque ${ }^{\mathrm{TM}}$ gradient centrifugation following leukapheresis of healthy seronegative donors. Monocytes and lymphocytes were further separated using countercurrent centrifugal cell elutriation as previously described [45]. Macrophages were prepared from elutriated monocytes by differentiation in $100 \mathrm{~mm}$ square Petri dishes (Bibbi Sterilin Ltd., Stone Staffs, UK) in DMEM 
supplemented with $10 \%$ human serum pooled from multiple donors, $2 \mathrm{mM}$ L-glutamine and antibiotics (MØ medium) [46,47]. After 7 to 14 days of differentiation in the absence of exogenous growth factors, the monocyte-derived macrophages (MDM) were detached (by incubation in DBPS at $4{ }^{\circ} \mathrm{C}$ ) and plated immediately in 96 and/or 48 well plates in the presence of TNF- $\alpha$, IL-4, IL-10 or IL-13 (100 or $200 \mu \mathrm{L}$ of cell suspensions $\left(35 \times 10^{3}\right.$ or $\left.70 \times 10^{3} \mathrm{MDM}\right)$ were added to equal amount of $\mathrm{M} \varnothing$ medium, containing $2 \times$ the desired final concentration of the cytokines). Macrophages were further incubated for $48 \mathrm{~h}$ before being assessed for fusion with the filovirus envelope (Env) pseudotyped, BLaM containing VLP. Based on previously published studies [48-50], the final cytokine concentrations were set at $20 \mathrm{ng} / \mathrm{mL}$, unless otherwise indicated in the figure legends. There were 96 well black, clear plastic (Costar) or glass bottom (Greiner Bio) plates, suitable for fluorescent microscopy used for the experiments analyzed by Laser Scanning Cytometer. For the experiments analyzed by Flow cytometry, the cells were cultured in 48 well Nunc plastic plates. Infections were performed in triplicate as each well was evaluated by Laser Scanning Cytometry. Alternatively, the cells from the tree wells were combined in one tube before analysis by Flow Cytometry.

\subsection{Cell Viability}

Cell viability was evaluated using the Promega CellTiter-Glo ${ }^{\circledR}$ Luminescent Cell Viability Assay, which is based on measuring the intracellular ATP levels as a marker of cellular metabolic activity.

\subsection{BLaM Entry Assay}

Filovirus GP pseudotyped, $\beta$-lactamase (BlaM)-containing virus particles were produced by co-transfection of 293 T cells with plasmids encoding VP-40 BlaM, VP-40 and the relevant filovirus surface glycoprotein. The VLP-containing supernatants were collected after 24 and $48 \mathrm{~h}$, subjected to low-speed centrifugation and low-protein binding $0.45 \mu \mathrm{m}$ filtration to remove cell debris and then further concentrated by ultracentrifugation. The influenza HA and NA pseudotyped VLP were generated by co-transfecting 293T cells with plasmids encoding the relevant influenza proteins, the packaging plasmid psPAX2 and the Vpr-BlaM encoding plasmid pMM310. The HA/NA VLP were processed the same way as the filovirus VLP, except no further concentration by ultracentrifugation was necessary. The HA from the highly pathogenic A/Vietnam 2004 (H5N1) strain appears to be cleaved in the virus producing cells [51] and, therefore, does not require addition of exogenous trypsin or an alternative protease during the in vitro infection. The different filovirus VLP preps used in our studies were found to be relatively equivalent (based on number of particles per unit volume) by tests performed using NanoSight LM10 (Malvern Panalytical, Malvern, UK) and/or ViroCyt 3100 (ViroCyt/Sartorius, Boulder, CO, USA).

After infection for $3.5 \mathrm{~h}$ in DMEM, supplemented with L-glutamine, the cells were washed twice with phenol red and serum-free medium (DMEM with no phenol red, containing 2 mM L-glutamine, $25 \mathrm{mM}$ HEPES, $2.5 \mathrm{mM}$ of the nonspecific anion transport inhibitor probenecid) and loaded with the fluorescent dye CCF2/AM ( $2 \mu \mathrm{M}$ final concentration in phenol red and serum free medium) for $1.5 \mathrm{~h}$, washed twice with phenol red and serum free medium to remove the extracellular dye and incubated in phenol red free DMEM with 10\% FCS, 2mM L-glutamine, 25mM HEPES and $2.5 \mathrm{mM}$ probenecid for $12-14 \mathrm{~h}$ prior to fixing with $1.6 \%$ paraformaldehyde. The extent of CCF2/AM cleavage by the virus-introduced intracellular BlaM, detected by the change in dye emission from the green to the blue spectrum, was evaluated by measuring the fluorescence using Laser Scanning Cytometer (CompuCyte, Cambridge, MA, currently ThorLabs) or BD LSR II Cell Analyzer generating light at $407 \mathrm{~nm}$ and equipped with HQ460/10 and HQ530/20 filters for detection of the blue and green emission, respectively. Separate negative controls (mock infection) were prepared for both control and cytokine-treated cells but, in general, insignificant difference was observed in the capacity of the cells to uptake, retain and/or spontaneously cleave the CCF2/AM dye. The cells prepared for analysis by Laser Scanning Cytometry were also stained with the nuclear dye DRAQ5 (in combination with CCF2/AM) to improve the discrimination of individual cells, which were adjacent (in contact) with each other. On average, 
5000 cells per sample were analyzed by Laser Scanning Cytometry and at least 10,000 cells per sample were analyzed by Flow cytometry.

The statistical analyses ( $p$ value calculations) were performed using GraphPad Prism software (unpaired two-tailed $t$ test).

\subsection{Flow Cytometry}

A. Surface Staining: MDM (106 cells/sample) were pre-treated with IL-10 $(20 \mathrm{ng} / \mathrm{mL})$ or cytokine resuspension buffer in 6 well Nunc tissue culture plates for $48 \mathrm{~h}$ before being detached by pre-incubation in DPBS (without $\mathrm{Ca}^{2+}$ and $\mathrm{Mg}^{2+}$ ) at $4{ }^{\circ} \mathrm{C}$ and gentle scraping. The cells were washed once with DPBS supplemented with $3 \%$ bovine serum albumin (BSA) and incubated for 30 min at $4{ }^{\circ} \mathrm{C}$ with FcR blocking reagent (Miltenyi Biotec $\mathrm{GmbH}$ ). Subsequently, the samples were incubated for additional $1.5 \mathrm{~h}$ at $4{ }^{\circ} \mathrm{C}$ with primary antibodies, washed $3 \times$ times (DBPS plus $2 \%$ BSA) and either fixed in $1.6 \%$ paraformaldehyde (when fluorescently labeled primary antibodies were used), or further incubated with the relevant fluorophore conjugated secondary antibodies for $1 \mathrm{~h}$ at $4{ }^{\circ} \mathrm{C}$, washed three times and fixed. Matching fluorescently labeled or unconjugated antibodies without specific binding activity were used as isotype controls. For the Niemann-Pick cholesterol transporter 1 (NPC-1) and cathepsin L labeling, the detached MDM were permeabilized and processed using the Foxp3/Transcription Factor Staining Buffer Set (Thermo Fisher Scientific), following manufacturer's instructions with the addition of FcR blocking reagent incubation step. The fluorescent labeling of the viable cell populations (defined by FSC/SSC) was evaluated using BD LSR II or BD FACSCanto II cell analyzers. The data were processed and further analyzed using WinList software (Verity Software House, Topsham, MA, USA).

B. EBOV GP binding studies: The recombinant proteins wild-type receptor binding region (wtRBR) and the binding deficient 4merRBR, linked to rabbit IgG-Fc, and used to label cells of interest, were previously described [52,53]. In brief, wtRBR-Fc contains $\mathrm{GP}_{1}$ residues 57 to 149 . The 4merRBR-Fc construct encodes mutations substituting the 4 lysine residues in $\mathrm{GP}_{1}$, found to be critical for RBR binding (K95A/K114A/K115A/K140A). Filovirus GP pseudotyped, green fluorescent protein (GFP)-containing virus particles were produced by co-transfection of $293 \mathrm{~T}$ cells with plasmids encoding VP-40-GFP, VP-40 and the EBOV Kikwit GP.The VLPs were concentrated and purified by ultracentrifugation through a sucrose cushion and were either kept frozen $\left(-80^{\circ} \mathrm{C}\right)$ or used immediately to label primary MDM for $2.5 \mathrm{~h}$ at $4{ }^{\circ} \mathrm{C}$ in a binding buffer (DPBS with $\mathrm{Ca}^{2+}$ and $\mathrm{Mg}^{2+}$ supplemented with $0.5 \%$ HSA), gently washed twice with ice cold binding buffer, fixed with paraformaldehyde and analyzed by flow cytometry (BD LSRII cell analyzer). To evaluate more accurately the EBOV GP binding we calculated and compared the staining indexes (SI) of the negative and positive pairs of mock and IL-10 treated MDM as previously described [54,55] (SI = mean positive - mean negative/ $\left.2 \times \mathrm{SD}_{\text {negative }}\right)$

\subsection{Microarray Analysis}

Primary MDM $\left(3 \times 10^{6}\right.$ cells/sample) were mock treated (cytokine resuspension buffer $-0.5 \%$ HSA in DPBS) or pre-incubated with $20 \mathrm{ng} / \mathrm{mL}$ IL-10 for $48 \mathrm{~h}$ before cell mRNA was extracted and tested using the Qiagen RNeasy Kit and CS3011 Illumina Gene Exp. Beadchip, respectively. The microarray assay and analysis were performed at Qiagen (SABiosciences, Service Core for Gene Expression and Genomic Analysis, Frederick, MD).

\subsection{Western Blot}

In general, the samples were analyzed using the Invitrogen NuPAGE/Western blot system following manufacturer's instructions. MDM $\left(2 \times 10^{6}\right.$ cells/sample) were IL-10 or mock treated for $48 \mathrm{~h}$ before being detached (pre-incubation in DPBS without $\mathrm{Ca}^{2+}$ and $\mathrm{Mg}^{2+}$ at $4{ }^{\circ} \mathrm{C}$ and gentle scrapping) and lysed with RIPA lysis buffer plus protease inhibitors. $20 \mu \mathrm{L}$ of each sample were combined with LDS $(4 X)$ concentrated sample buffer and $10(x)$ concentrated reducing agent and loaded onto $4-12 \%$ Bis-Tris gels for electrophoresis. The samples were transferred to a nitrocellulose membrane, which 
was further developed using anti-cathepsin L (clone 33/1, Invitrogen) or anti-cathepsin B (clone 1J37, GeneTex) antibodies.

\section{Results}

\subsection{IL-10, But Not TNF- $\alpha$, IL-4 or IL-13, Increases Entry of EBOV GP Kikwit Pseudotyped VLP in Primary} Human MDM

For our initial studies, we explored the effects of TNF- $\alpha$, IL-4, IL-13 and IL-10 pre-incubation on the ability of primary human MDM from three healthy donors to support the fusion of VLP

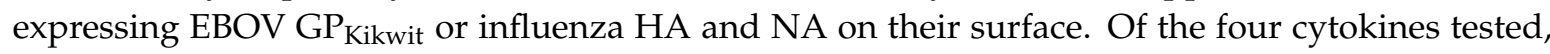
only IL-10 consistently enhanced EBOV GP Kikwit VLP entry (Figure 1A). This is in agreement with a previous study [56] reporting that addition of IL-4 to macrophage colony stimulating factor (M-CSF) during monocyte/macrophage differentiation did not significantly affect EBOV VLP entry. The slight IL-10-induced reduction in HA/NA VLP entry (Figure 1A) also appears consistent with previous observations [57] regarding the effects of macrophage polarization on influenza infection of these cells.

Due to the high degree of variability in the published methods with respect to the concentrations of TNF- $\alpha$, IL-4, IL-13 and/or IL10 (ranging from $5 \mathrm{ng} / \mathrm{mL}$ to $100 \mathrm{ng} / \mathrm{mL}$ ) and/or the incubation times (from 4 to $175 \mathrm{~h}$ ) used to elicit differential macrophage polarization $[48,49,58-66]$, we sought to confirm that our experimental protocol induces the expected phenotypic changes. We chose a cytokine concentration $(20 \mathrm{ng} / \mathrm{mL})$ and an incubation time $(48 \mathrm{~h})$ close to the averages reported in the previous studies $[48,49,59,63]$. As a marker of cytokine effects $[44,65]$, we used flow cytometry to assess CD206 cell surface expression on the MDM from one of the donors whose cells were also used in a virus entry/BlaM experiment summarized in Figure 1A. Consistent with published data regarding the CD206 expression on M2a, M2c or M1 macrophage phenotypes [50,62,65], CD206 was strongly upregulated by IL-4 and IL-13, increased to a lesser extent by IL-10, and slightly decreased by TNF- $\alpha$, compared to the mock treated cells (Figure 1B). Because of the enhancing effect of IL-10 on EBOV GP Kikwit $_{\text {VLP entry, we }}$ further characterized the IL-10 induced macrophage phenotype by flow cytometry and/or microarray analysis of control (mock treated with $0.5 \%$ HSA) and IL-10 $(20 \mathrm{ng} / \mathrm{mL})$ treated MDM from several additional healthy donors. The results from our microarray analysis (Supplemental Table S2) revealed a significant increase in Suppressor of Cytokine Signaling 3 (SOCS3), which is considered a consensus marker for IL-10 treated human macrophages [67]. We also confirmed the presence of increased levels of CD163 and IL21R by microarray analysis (Supplemental Table S1) and flow cytometry, previously reported to be upregulated by IL10 $[58,65,68,69]$.

After the initially observed IL-10 enhancing effect on EBOV-GP Kikwit $_{\text {VLP entry in several }}$ donors [70], we subsequently tested the effect of IL-10 in MDM obtained from more than 30 healthy individuals. Figure 2A summarizes the results from 25 donors, whose cells were analyzed using an iCys laser scanning cytometer. Figure 2B, shows fluorescent images of mock and IL-10 treated cells from one representative donor. 
A

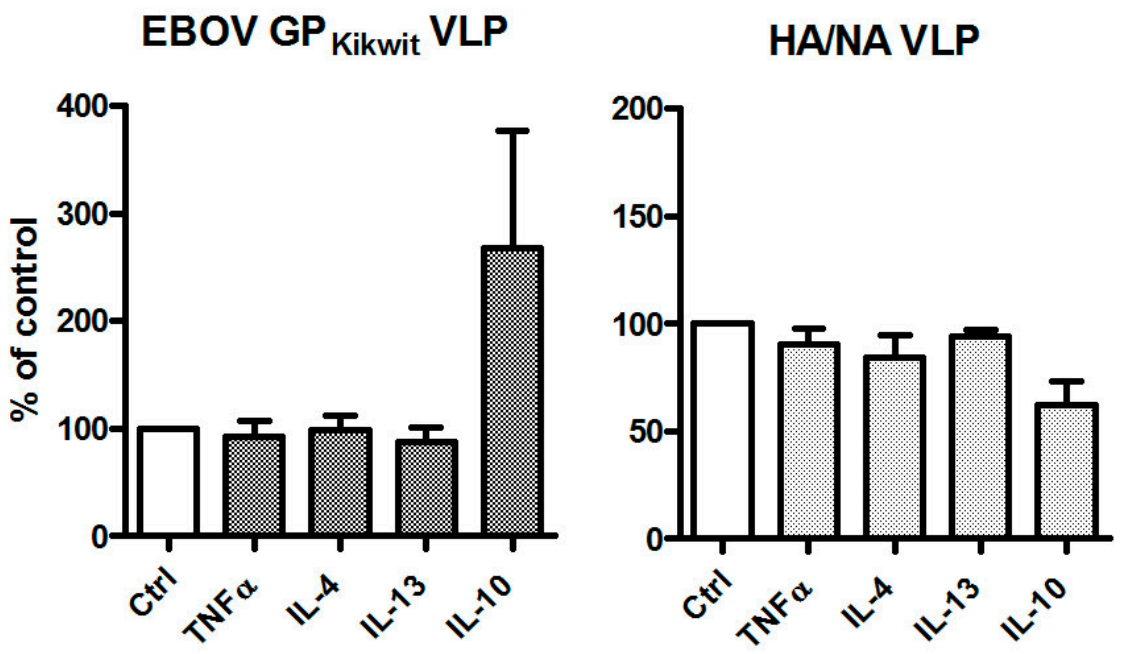

B

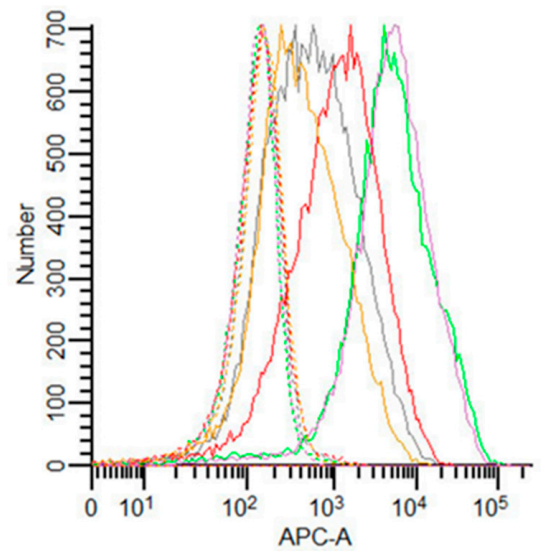

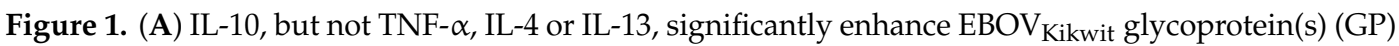
pseudotyped virus-like particles (VLP) entry in primary human monocyte-derived macrophages (MDM). MDM from three healthy donors were pre-treated with TNF- $\alpha$, IL-4, IL-13 or IL10 (all at concentrations of $20 \mathrm{ng} / \mathrm{mL}$ ) for $48 \mathrm{~h}$ prior to incubation with $\mathrm{EBOV}_{\text {Kikwit }} \mathrm{GP}$ or influenza hemagglutinin/neuraminidase (HA/NA) pseudotyped VLP for $3.5 \mathrm{~h}$ at $37^{\circ} \mathrm{C}$. Subsequently, the cells were processed at room temperature, washed twice, loaded with CCF2/AM fluorescent dye for $1.5 \mathrm{~h}$, washed again (2 times), incubated overnight to allow the cleavage of CCF2/AM by the VLP introduced $\beta$-lactamase (BlaM) and fixed in $1.6 \%$ paraformaldehyde. The extent of CCF2/AM cleavage, resulting in the change of the emission spectrum from $530 \mathrm{~nm}$ (green) to $460 \mathrm{~nm}$ (blue), was assessed by Laser Scanning Cytometry. The levels of VLP fusion with mock-treated MDM (treated with an equivalent volume of cytokine re-suspension buffer) were assumed to be $100 \%$. Each treatment condition was performed in triplicate wells and the mean value(s) was used to calculate "\% of control". The data from the individual experiments, used to generate Figure 1A, are included in Table S1A through Table S1H (donor \#1, donor \#2 and donor \#17). (B) TNF- $\alpha$, IL-4, IL-13 or IL-10 affect CD206 expression in a cytokine-specific manner. Aliquots of MDM from one of the donors presented in Figure 1A were pre-incubated with TNF- $\alpha$, IL-4, IL-13 or IL10 $(20 \mathrm{ng} / \mathrm{mL})$, detached by incubation in EDTA/EGTA buffer at $4^{\circ} \mathrm{C}$ and gentle scraping, and then labeled with phycoerythrin-conjugated anti-CD206 monoclonal antibody. CD206 cell surface expression was evaluated using BD FACSCanto II cell analyzer. The gray, yellow, red, green and purple lines represent control (mock treated), TNF- $\alpha$, IL-10, IL-4 and/or IL-13 pre-incubated cells, respectively. The dash lines with the same colors represent the relevant isotype controls. 
A

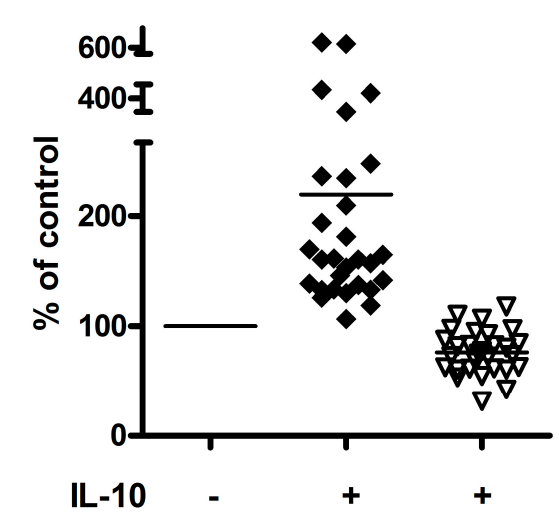

B

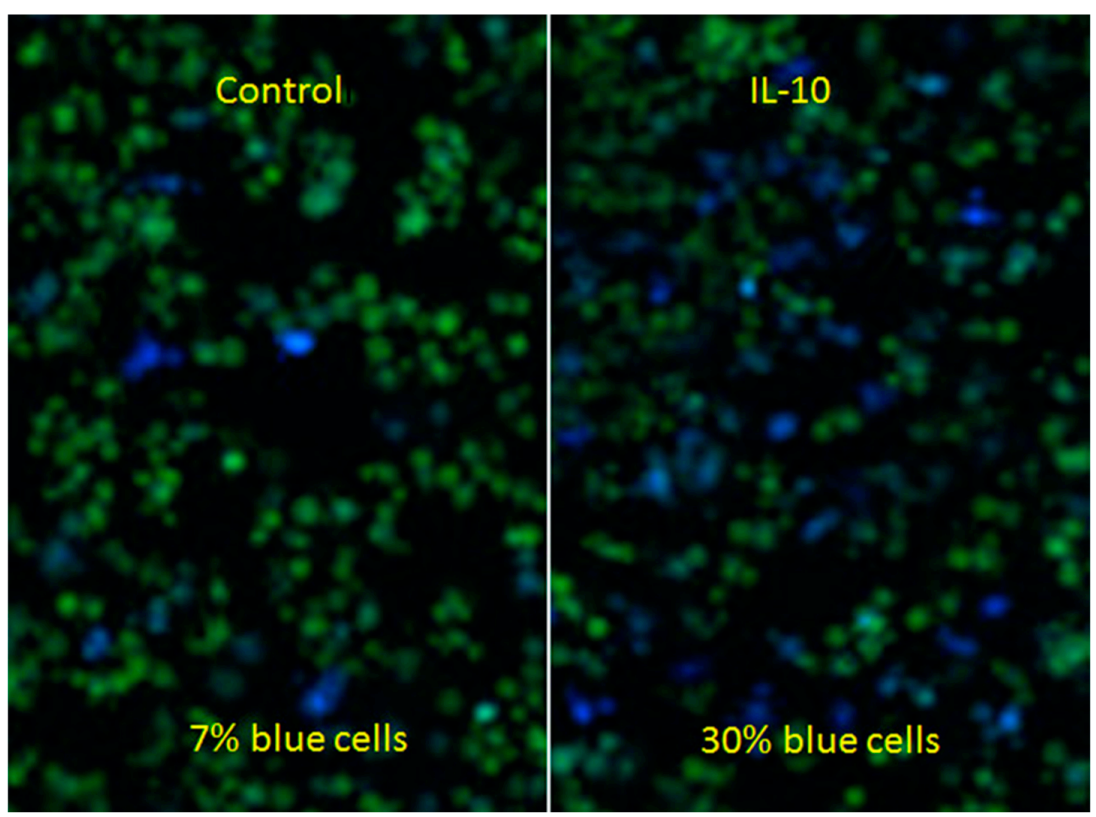

C

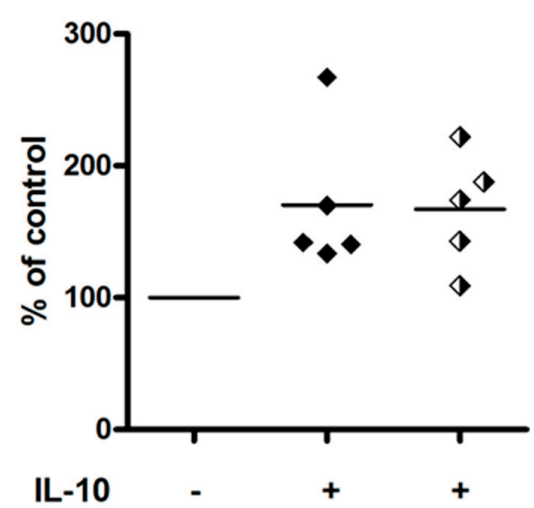

Figure 2. Cont. 
D

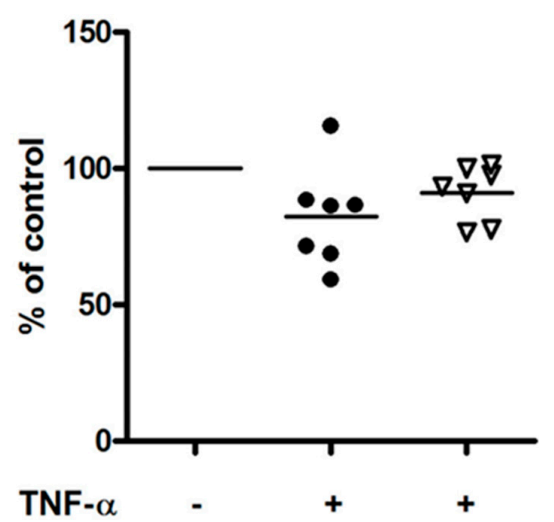

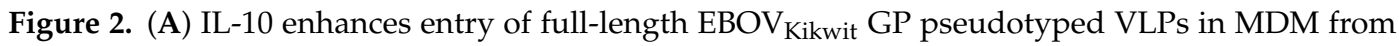
multiple donors $(n=25)$. MDM were pre-incubated with IL10 $(20 \mathrm{ng} / \mathrm{mL})$ for $48 \mathrm{~h}$ prior to infection. The cells were processed and the EBOV Kikwit VLP (solid diamonds) entry/fusion was analyzed by Laser Scanning Cytometry as described in the Materials and Methods and Figure 1. BlaM-containing virus particles, pseudotyped with influenza HA/NA (white triangles), served as controls. The levels of virus entry in mock-treated MDM (with an equivalent volume of cytokine re-suspension buffer) were assumed to be $100 \%$. The graph summarizes data from multiple experiments and includes the results

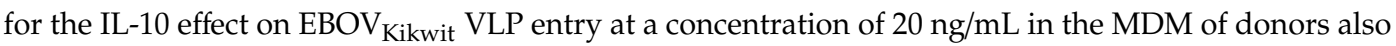
used to generate the data presented in Figure 1, Figure 2B, Figure 3, Figure 4A-C, Supplemental Figure S1 and Supplemental Figure S2. The data, including statistical analysis, from the multiple experiments, used to generate Figure 2A, are summarized in Table S1A,B. (B) Representative fluorescent images, generated by the iCys Laser Scanning Cytometer using MDM from one of the donors, show increased numbers of cells fused with the EBOV GP VLPs (blue cells) after IL-10 treatment. No significant difference was observed in the background fluorescence of uninfected IL-10 or mock treated cells. (C) IL-10 induced enhancement is independent of the EBOV Kikwit $_{\text {GP }} \Delta$ mucin domain. MDM from 4 healthy donors were infected in parallel with VLPs pseudotyped with either full length EBOV Kikwit $_{\text {GP }}$ (solid diamonds) or $\mathrm{EBOV}_{\text {Kikwit }} \Delta$ mucin GP (black and white diamonds). The cells were processed and the "\% of control" was calculated as described for Figure 1. The data from the individual experiments, used to generate this figure, are included in Table S1A,B,I (donors \#10, \#11, \#13, \#15 and \#29). (D)

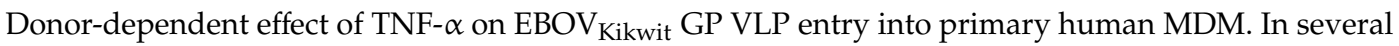
different experiments, cells from a total of seven healthy donors were incubated with TNF- $\alpha(20 \mathrm{ng} / \mathrm{mL})$

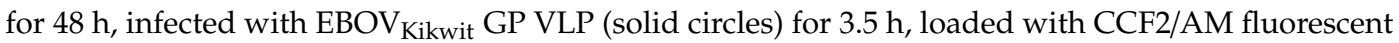
dye and processed as described in Materials and Methods. The subsequent evaluation of VLP fusion was performed either by Laser Scanning Cytometry (6 donors) or Flow cytometry (1 donor). The levels of VLP fusion with mock-treated MDM (equivalent volume of cytokine re-suspension buffer) were assumed to be $100 \%$. VLPs pseudotyped with influenza HA/NA served as controls (open triangles). The data from the individual experiments, used to generate Figure 2D are summarized in Table S1C,F. 


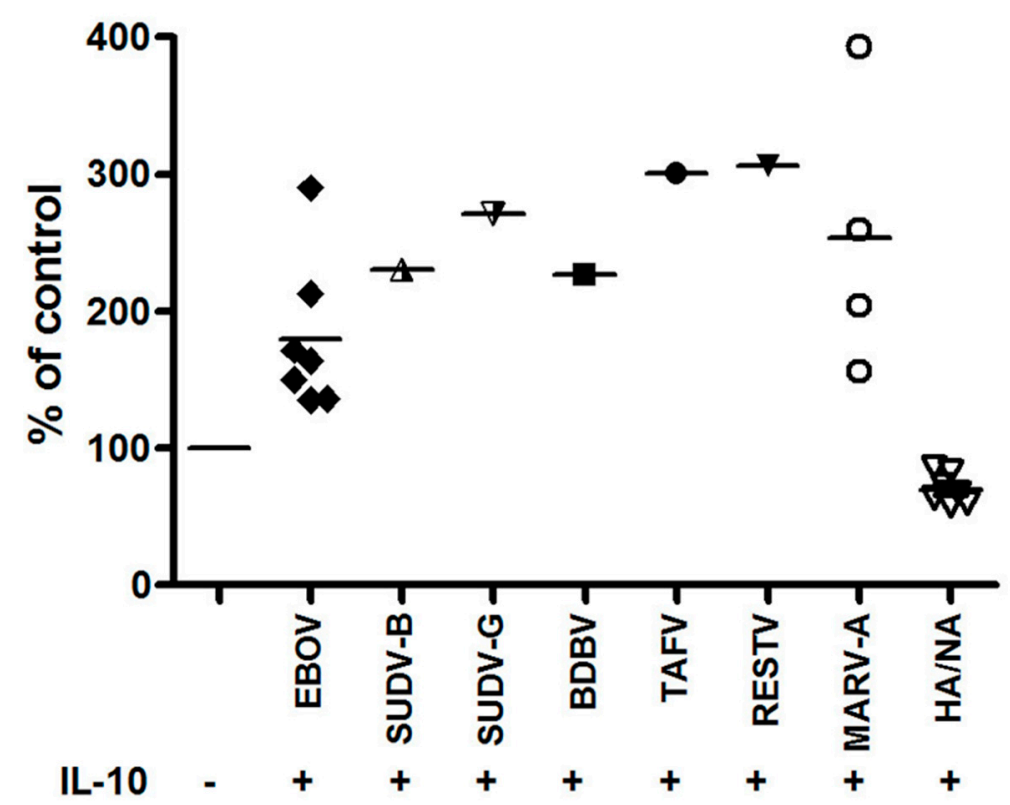

Figure 3. IL-10 enhances fusion of primary MDM with VLPs pseudotyped with envelope glycoproteins from all clinically significant filovirus species. Cells were pre-incubated with $20 \mathrm{ng} / \mathrm{mL}$ IL-10 or DPBS supplemented with $0.5 \%$ HSA (mock treated), infected, loaded with CCF2/AM, processed and analyzed by Flow cytometry as described in Materials and Methods. The figure summarizes the results from several different experiments, utilizing MDM from a total of seven different donors. In each experiment, MDM were infected with EBOV $_{\text {Kikwit }}$ GP VLP (solid diamonds) in parallel with one or more different VLP types, pseudotyped with the surface glycoprotein of one of the indicated filovirus species. Data from one of the individual donors are presented in Supplemental Figure S3. Influenza HA/NA pseudotyped virus particles served as a control (open triangles).

MDM from seven additional donors were analyzed by flow cytometry for their ability to fuse with

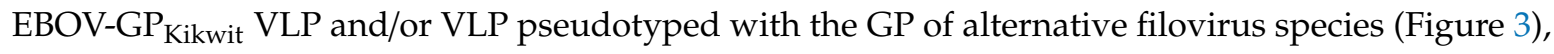
and the results were consistent with our observations by laser scanning cytometry. The effect of IL-10 (fold increase) on virus entry was more pronounced when the MDM were incubated with a reduced number of EBOV-GP Kikwit VLPs (Supplemental Figure S1). We also compared the fusion of primary MDM with VLPs pseudotyped with full length EBOV-GP Kikwit $_{\text {or }} \Delta$ mucin EBOV-GP Kikwit and observed comparable levels of IL-10 induced enhancement of VLP entry (Figure 2C), i.e., the effect of IL-10 does not appear to be dependent on the mucin domain of EBOV GP.

The enhancing effect of IL-10 was demonstrated as well for EBOV-GP Kikwit $_{\text {VLP generated }}$ using the retrovirus-derived psPAX2 packaging plasmid and a HIV-1 Vpr-BLaM encoding construct (pVpr-Blam) (Supplemental Figure S2).

In parallel with IL-10, the effect of the pro-inflammatory cytokine TNF- $\alpha$ was tested in MDM isolated from 7 healthy donors (Figure 2D). Despite the observed donor to donor variability, in contrast to IL-10, the TNF- $\alpha$ pre-incubation displayed a tendency to slightly decrease EBOV $_{\text {Kikwit }}$ VLP entry (in 6 of the 7 donors tested, Table S1C). TNF- $\alpha$ did not have a significant effect on HA/NA VLP entry into primary MDM (Table S1F). 
A
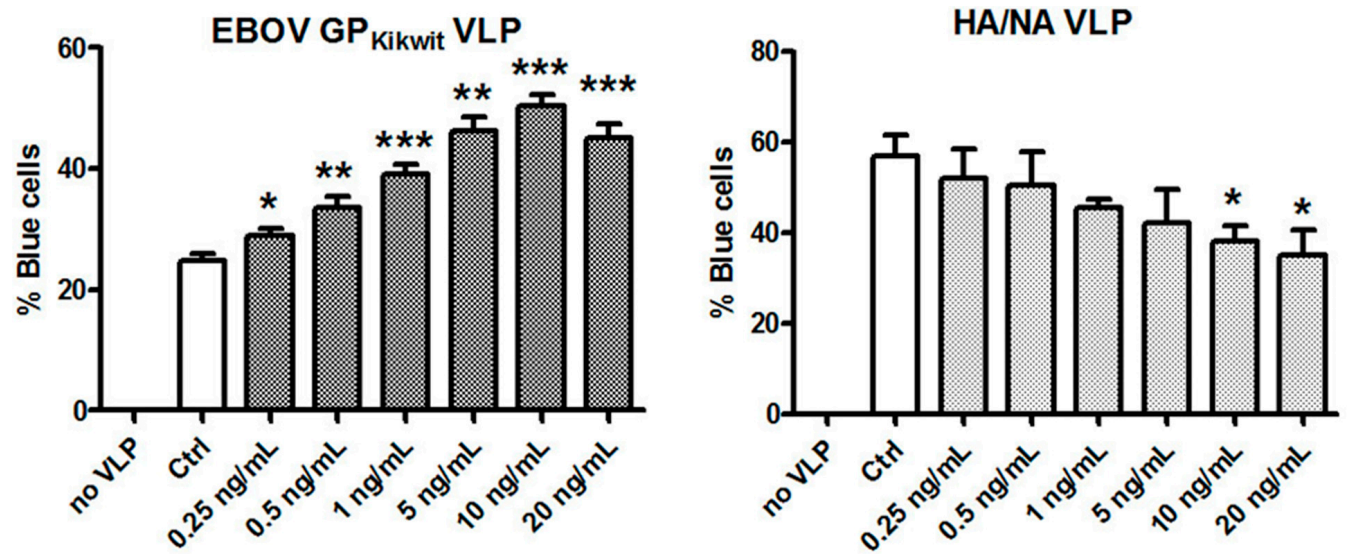

B
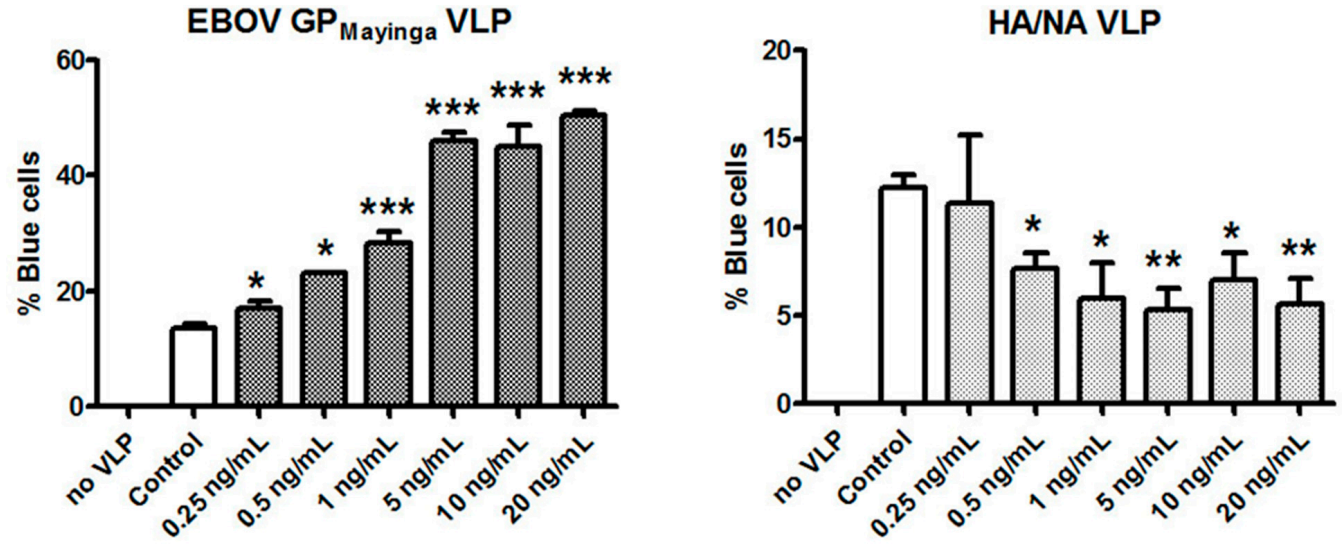

C

EBOV GP Makona VLP

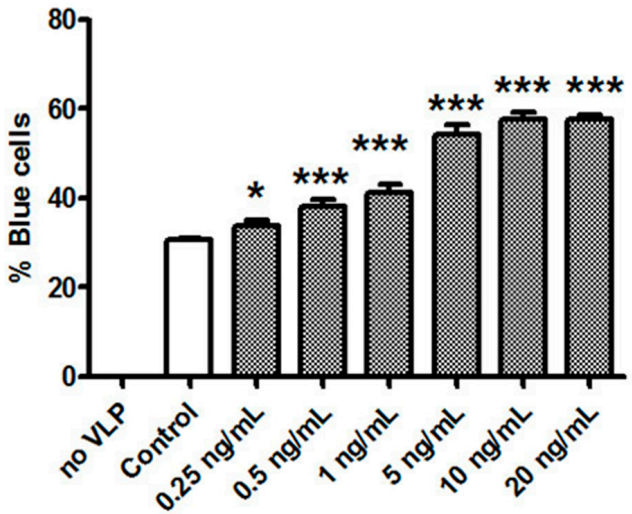

HA/NA VLP

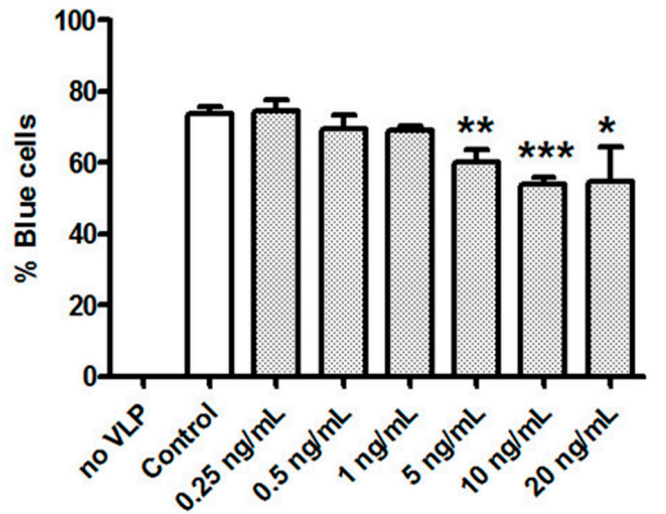

Figure 4. IL-10 enhances fusion of primary MDM with VLPs pseudotyped with EBOV GP in a dose-dependent manner, but has no significant effect or slightly inhibits entry of VLPs pseudotyped with influenza HA/NA. MDM from three different healthy donors were pre-incubated for $48 \mathrm{~h}$ with increasing concentrations of IL-10 and infected for $3.5 \mathrm{~h}$ with VLPs pseudotyped with the surface glycoproteins of the Kikwit (Panel A), Mayinga (Panel B) or Makona (Panel C) strains, respectively. Subsequently, the cells were washed, loaded with the fluorescent dye CCF2/AM and prepared for analysis by Laser Scanning Cytometry as described in Material and Methods. ${ }^{*} p \leq 0.05 ;{ }^{* *} p \leq 0.01$; $* * * p \leq 0.001$. 
3.2. IL-10 Augments the Macrophage Fusion with VLPs Pseudotyped with the Surface Glycoproteins of All Clinically Relevant Filovirus Species

Subsequent to testing the IL-10 effect on EBOV GP Kikwit VLP entry, we demonstrated the ability of IL-10 to enhance the fusion of primary macrophages with VLP pseudotyped with the surface glycoproteins from most of the clinically relevant filovirus species: Sudan ebolavirus, strains Gulu and Boneface, TaïForest ebolavirus, Bundibugyo ebolavirus, Reston ebolavirus and Marburg Marburgvirus, strain Angola. The data presented in Figure 3 were generated using MDM obtained from 7 healthy donors. The cells from each donor were infected in parallel with EBOV GP Kikwit VLP and one or more additional VLPs, pseudotyped with one of the alternative filovirus glycoproteins (results from one representative donor are provided in Figure S3).

Although the level of IL-10 induced enhancement was similar across the different filovirus VLP tested, the data suggest that the VLPs pseudotyped with glycoproteins derived from more pathogenic species, such as EBOV, may fuse at a higher initial rate with primary human MDM (Figure S3).

\subsection{IL-10 Enhances the Entry of EBOV GP VLPS Into MDM at Concentrations Observed In Vivo}

The IL-10 concentrations typically used to induce the M2c phenotype in vitro significantly exceed the IL-10 levels observed in vivo. Therefore, we tested the ability of IL-10 at concentrations ranging between $0.25 \mathrm{ng} / \mathrm{mL}$ and $20 \mathrm{ng} / \mathrm{mL}$ to affect the entry of VLPs pseudotyped with the surface glycoproteins of three EBOV isolates: Kikwit (Figure 4A), Mayinga (Figure 4B) and Makona (Figure 4C) into primary MDM.

We observed a significant, dose-dependent increase of entry for all three different types of VLPs, starting at the lowest IL-10 concentration of $0.25 \mathrm{ng} / \mathrm{mL}$. Several previous studies have reported serum/plasma IL-10 levels in the $0.25 \mathrm{ng} / \mathrm{mL}-1 \mathrm{ng} / \mathrm{mL}$ range during EBOV infection, particularly in patients having an unfavorable outcome due to the disease [1-3,6,8,9] (see Supplemental Table S3 for more details). Furthermore, IL-10 levels up to $8 \mathrm{ng} / \mathrm{mL}$ have been detected during infection with SUDV [10]. It has also been established that EBOV GP and/or replication incompetent EBOV GP pseudotyped VLP are capable of inducing IL-10 secretion in cell culture models at concentrations between 0.025 and $5 \mathrm{ng} / \mathrm{mL}$ [16-18,26-28]. Because of the variety of methods and reagents used, it may be impossible to accurately compare the IL-10 levels established in different studies. However, taken in its entirety, the clinical and in vitro data support the concept that IL-10 levels higher than $0.25 \mathrm{ng} / \mathrm{mL}$ are very likely to be present in vivo at the sites of filovirus replication, given the in vitro established ability of filovirus surface glycoproteins to induce IL-10 secretion.

In contrast to our findings with EBOV GP pseudotyped VLPs, but consistent with our previous observations, IL-10 reduced the entry of influenza HA/NA VLPs into primary MDM in a dose-dependent manner (Figure 4 A, B, C).

\subsection{The IL-10-Mediated Increase of EBOV-GP VLP Entry into Primary Human MDM May Occur at Binding} and Potentially Post-Binding Steps

By using the EBOV GP-derived recombinant protein RBR-Fc [52,53] (Figure 5A) or GFP-containing VLPs (Figure 5B), we established by flow cytometry analysis that IL-10 pre-incubation increased EBOV GP binding to primary human MDM. 

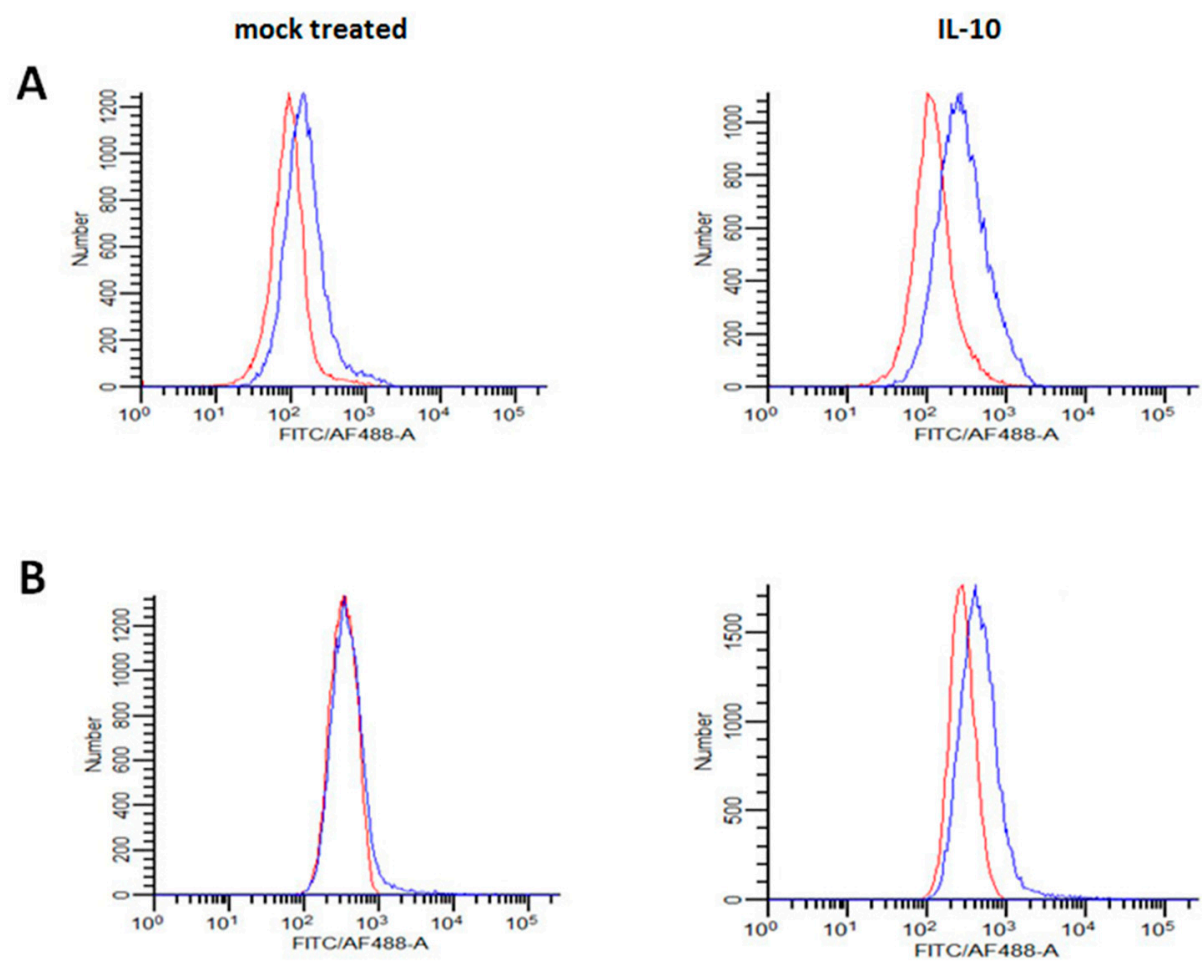

Figure 5. Increased binding of EBOV GP to IL-10 treated primary human MDM. (A) Cells were pre-treated for $48 \mathrm{~h}$ with IL-10 and incubated for $1.5 \mathrm{~h}$ at $4{ }^{\circ} \mathrm{C}$ in binding buffer $\left(0.5 \% \mathrm{HSA}\right.$ in $\mathrm{Ca}^{2+}$ and $\mathrm{Mg}^{2+}$ containing DPBS) with a recombinant protein, consisting of the EBOV GP receptor binding domain $\left(\mathrm{GP}_{1}\right.$ residues 57 to 149$)$, fused to the Fc portion of rabbit IgG. MDM incubated with the binding deficient construct 4merRBR-Fc served as a negative control (red line). Subsequently, the MDM were washed, labeled with FITC conjugated polyclonal goat anti-rabbit antibody, fixed with paraformaldehyde and analyzed by Flow Cytometry. The staining indexes for the mock and IL-10 treated pairs of negative and positive samples are 0.3593 and 0.7086 , respectively (for details regarding the staining indexes calculation please refer to Material and Methods). (B) Alternatively, MDM were incubated for $2.5 \mathrm{~h}$ at $4{ }^{\circ} \mathrm{C}$ with GFP-containing (VP40-GFP) VLPs pseudotyped with full length EBOV $_{\text {Kikwit }}$ GP (blue line). Full length EBOV GP-pseudotyped VLPs, which do not contain GFP, served as a negative control (red line). The staining indexes for the mock and IL-10 treated pairs negative and positive samples are 0.8444 and 1.8228 , respectively.

To further investigate the potential mechanism(s) responsible for the IL-10-mediated enhanced EBOV GP pseudotyped VLP entry, we performed a microarray analysis of IL-10 and/or mock treated MDM. The microarray study (Supplemental Table S2) did not clearly define a factor(s) responsible for the increased EBOV GP binding but suggested that IL-10 may also affect filovirus entry at both binding and post-binding steps. Of the molecules previously implicated in playing a role in filovirus cellular entry [lectins, TAM receptor tyrosine kinases (Tyro3, Axl, Mer), TAM receptor tyrosine kinases ligands (Protein S), T cell immunoglobulin and mucin domain (TIM) proteins, Toll-like receptors, integrins ( $\alpha \mathrm{V}$ and $\beta 1$ ), cathepsins (L and B) and Niemann-Pick cholesterol transporter 1 (NPC1)] (reviewed in [71-73]), we found increased mRNA expression of integrin $\alpha \mathrm{V}$, cathepsin L, Protein $S$ and Axl. Subsequently, we confirmed by immuno-fluorescence the upregulation of integrin $\alpha \mathrm{V} / \mathrm{CD} 61$ and Axl. Integrin $\beta 1 / C D 29$ mRNA was not found to be increased using the microarray testing, but the MDM cell surface expression (assessed by flow cytometry) was slightly increased, most likely as a result of its association with $\alpha \mathrm{V} / \mathrm{CD} 61$ (data not shown). The microarray analysis did not find upregulation of TIM proteins, but revealed upregulated Protein S mRNA. Although largely unstudied for its potential role in virus entry, Protein $\mathrm{S}$ has the capability to bridge phosphatidyl serine (via its $\mathrm{N}$-terminal domain) of the virus membrane to the TAM receptors on the cell surface [74]. Cathepsin L, which is involved in 
the partial endosomal cleavage of EBOV GP to its fusion competent form, showed significant donor to donor variability (being upregulated by IL-10 in some, but not all, donors), when tested by flow cytometry and/or western blot (Supplemental Figure S4 and data not shown). No upregulation of NPC-1 was detected in primary MDM by microarray analysis or flow cytometry (data not shown).

\subsection{The Enhancing Effect of IL-10 on EBOV GP Kikwit-Mediated Fusion/VLP Entry in Primary Human MDM} Is Preserved in the Presence of Pro-Inflammatory Cytokines

In general, EBOV infection is characterized as having concomitantly increased levels of IL-10 and pro-inflammatory cytokines [1-3,8,9,33]. Initially, we investigated the IL-10 effect on EBOV Kikwit VLP entry (Figure 6A and Table S1C) in the presence of TNF- $\alpha$ at cytokine concentrations ( $20 \mathrm{ng} / \mathrm{mL}$ ) usually applied to induce macrophage phenotype changes in vitro (see Materials \&Methods). Using MDM

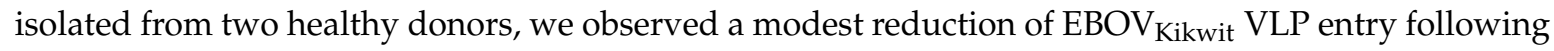
TNF- $\alpha$ pre-incubation, while IL-10 counteracted this effect (Figure 6A and Table S1C, MDM from one of the donors were analyzed using Laser scanning cytometry, while the cells from the other donor were analyzed by Flow cytometry). Although the differences were not statistically significant, both IL-10 and TNF- $\alpha$ slightly decreased the entry of HA/NA VLP in the primary MDM of these donors. The TNF- $\alpha$-induced reduction in $\mathrm{EBOV}_{\text {Kikwit }}$ VLP fusion appears consistent with previous findings $[2,4,5]$ showing that a strong pro-inflammatory cytokine response, including elevated TNF- $\alpha$ secretion, may be protective, at least in some donors, early in EBOV infection. Subsequently, we tested in parallel the effects on $\mathrm{EBOV}_{\text {Makona }}$ VLP entry in the presence of low concentrations of IL-10, potentially present during EBOV infection, with IL-10 applied alone or in combination with other cytokines, modeled after the cytokine profile characterized in non-survivors during the recent West Africa outbreak [3] and again observed increased VLP-MDM fusion in both cases (Figure 6B). The same combinations of IL-10 and pro-inflammatory cytokines had either no significant effect or decreased the entry of influenza HA/NA pseudotyped VLP in primary human MDM. Intriguingly, unlike high levels of TNF- $\alpha$ (Figure 6A), the pro-inflammatory cytokine cocktails (Figure 6B) do not show a tendency to counteract the enhancing effect of IL-10 on EBOV GP VLP entry. A unique signaling pattern induced by the cytokine cocktail, compared to TNF- $\alpha$ alone, may be one of the potential factors responsible for the observed difference. Studies are ongoing to further investigate this initial observation.
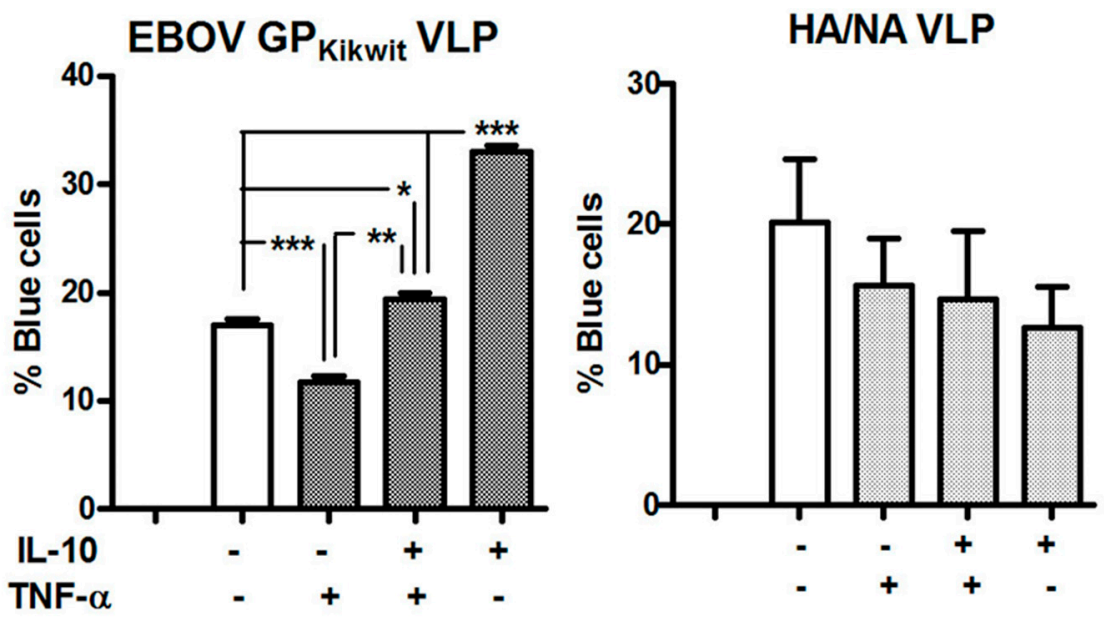

Figure 6. Cont. 
B
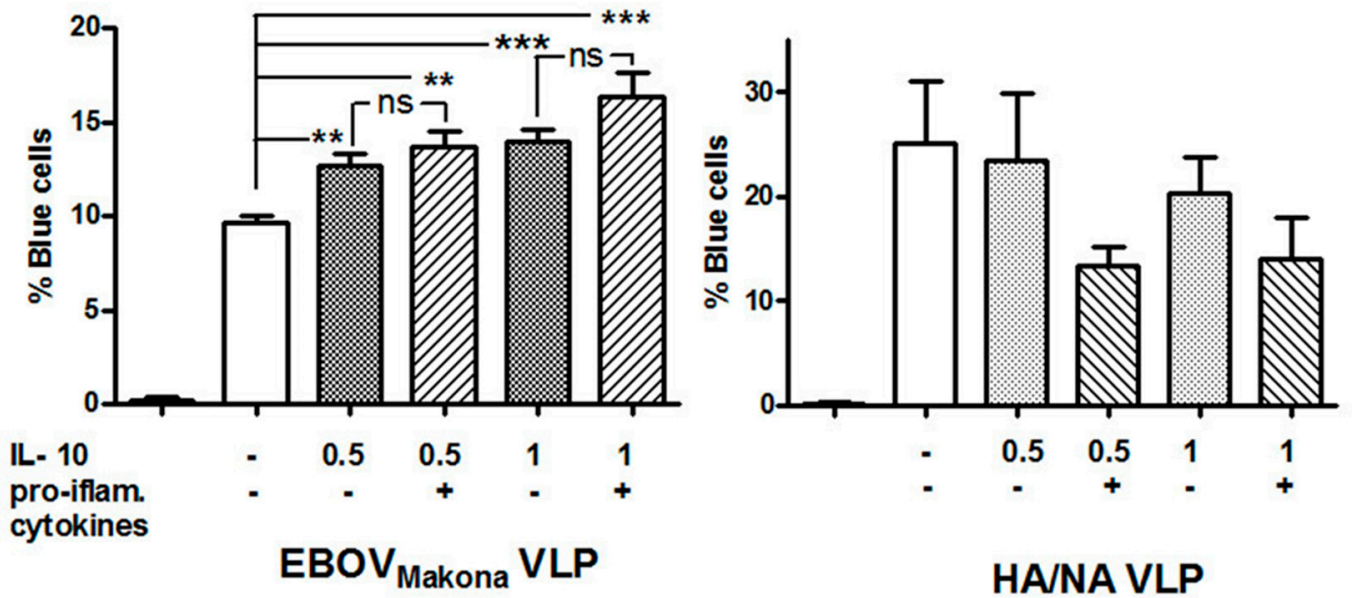

HA/NA VLP

Figure 6. The enhancing effect of IL-10 on EBOV VLP entry is preserved in the presence of pro-inflammatory cytokines. (A) MDM were pre-treated with IL-10, TNF- $\alpha$ or a combination of both for $48 \mathrm{~h}$ (IL-10 and TNF- $\alpha$ were used at a concentration of $20 \mathrm{ng} / \mathrm{mL}$ ) and infected with EBOV $\mathrm{V}_{\text {Kikwit }}$ GP VLP. The first columns from the left represent mock infected cells. There was no difference in the background fluorescence of mock-infected MDM incubated with cytokines or in medium alone. (B) MDM were pre-incubated with IL-10 $(0.5 \mathrm{ng} / \mathrm{mL}$ or $1 \mathrm{ng} / \mathrm{mL})$ or IL-10 plus a cocktail of pro-inflammatory cytokines (TNF- $\alpha, 0.1 \mathrm{ng} / \mathrm{mL} ; \mathrm{MIP}-1 \alpha, 0.1 \mathrm{ng} / \mathrm{mL} ; \mathrm{MIP}-1 \beta$ and MCP-1, 2ng/mL; IL-8, $0.5 \mathrm{ng} / \mathrm{mL}$ ) for $48 \mathrm{~h}$ before infection. After the $3.5 \mathrm{~h}$ infection period, the cells were prepared for analysis by Laser Scanning Cytometry as described in Materials and Methods. ${ }^{*} p \leq 0.05 ;{ }^{* *} p \leq 0.01 ;{ }^{* *} p \leq 0.001$; $\mathrm{ns}=$ not significant.

\section{Discussion}

Along with higher virus loads, increased IL-10 levels have consistently emerged as a prognostic factor for poor clinical outcomes in EBOV [1-3,8,9,33], SUDV [10] and/or BDBV [11] infection (see Supplemental Table S2 for details).

There is also evidence that the dynamics of IL-10 changes may be associated with filovirus pathogenicity. A comparison between an eight day long in vitro infection of human PBMCs with EBOV (Mayinga strain) and BDBV, which is associated with lower mortality rate, established higher IL-10 levels in the supernatants of EBOV infected cells up to day 5 post-infection with a peak on day 2, while the IL-10 concentration became higher in BDBV supernatants on days 6 and 8 post infection [13]. This observation appears consistent with a subsequent study which established higher IL-10 levels in fatal cases of BDBV infection in serum samples with a median time of collection 7 (non-survivors) to 7.5 days (survivors) post onset of illness [11]. Although a comparison among clinical studies should be made with caution because of differences in the study designs and methodologies, there are data suggesting that in EBOV [1,2] and/or SUDV [10,75] infections with high mortality rates, IL-10 is markedly elevated within the first $4-5$ days after the onset of symptoms. No clear pattern has been established for the 2014-2016 Makona EBOV outbreak, which had a relatively lower mortality rate ( 40-50\%) [76-78] compared to previous EBOV outbreaks [78-80]. Increased serum/plasma IL-10 levels in non-survivors, compared to survivors, were detected before day 7 of onset of symptoms in patients from Guinea $[3,9,81]$, but significantly higher IL-10 levels in fatal cases were detected only 7 days after symptom manifestation in serum samples collected from patients in Sierra Leone [33]. Intriguingly, the WHO Ebola Situation Report from 30 March, 2016, indicated a higher mortality rate (reported deaths among probable and suspected cases vs. all confirmed, probable, and suspected cases) in Guinea [(2543/3811) × $100=66.7 \%]$ compared to Sierra Leone [(3956/14124) $\times 100=28 \%]$. Whether distinct IL-10 responses were a contributing factor for the different mortality rates in Guinea and Sierra Leone during the Makona outbreak remains to be established. 
IL-10 changes have been shown to play a role not only in humans, but also in other species susceptible to filovirus infection:

Elevated IL-10 serum concentrations were detected in Cynomolgus macaques (over $10 \mathrm{ng} / \mathrm{mL}$ in some animals) infected with RESV [82]. Increased IL-10 plasma/serum levels were also observed in EBOV infected Cynomolgus macaques [76,83], but no significant changes in IL-10 were established in other studies using the same animal model [84,85]. Interestingly, no changes in IL-10 were reported when rhesus macaques were challenged intramuscularly (IM) with MARV-Angola [86], but multiple-fold increases in serum IL-10 levels were established in another study after aerosol exposure of rhesus macaques to the same virus [87]. These results suggest that the route of filovirus exposure may affect the changes in IL-10 levels during the subsequent infection and raise the question of whether the typical IM challenge of non-human primates (NHP) may be a factor for the less frequently observed IL-10 increase in these animals, compared to the naturally occurring filovirus infections in humans.

In addition to being a natural, usually asymptomatic host of RESV [88,89], domestic pigs are susceptible to and develop severe respiratory pathology in response to EBOV infection (after a combined intranasal, intraocular and oral challenge), which was associated with up to a 20-fold increase of IL-10 mRNA in the lung tissue of the infected animals [90,91].

Increased IL-10 levels were also found in the mouse model of EBOV infection [29-31,92]. The significance of IL-10 signaling in the pathogenesis of EBOV was further demonstrated [93] by showing that IL10 ${ }^{-/}$knock-out mice or mice treated with IL-10 specific anti-sense phosphorodiamidate morpholino oligomers (PMOs) had significantly lower virus titers and higher survival rate ( $70 \%$ vs. $30 \%$ ) after intraperitoneal challenge with mouse adapted EBOV. Specific antibody-mediated depletion experiments implied that NK cells and interferon- $\gamma\left(\right.$ IFN- $\gamma$ ) are required for the protection of IL10 ${ }^{-/}$ knock-out mice, leading to the hypothesis that IL-10 may aggravate EBOV infection via suppression of the immune system [93].

Our results indicate that, in addition to these general effects on the immune system, IL-10 can specifically influence filovirus infection by enhancing virus entry in primary human macrophages. After our initial observations [70], we consistently observed the enhancing effect of IL-10 on EBOV $\mathrm{GP}_{\text {Kikwit }}$ VLP entry in MDM isolated from more than 30 healthy donors (Figures 2A and 3). We subsequently established that the IL-10 effect on VLP entry is likely mediated at cell binding and post-binding steps (Figure 5). In principle, a scenario whereby higher IL-10 levels augment the ability of macrophages to support filovirus fusion appears consistent with a proposed mathematical model of EBOV disease suggesting that the higher viral load in non-survivors is associated with an accelerated conversion of "potential target cells" into "susceptible target cells" during infection [94].

We observed that IL-10 treatment increased the entry into primary human MDM of VLPs pseudotyped with the surface GP from all filovirus species tested, regardless of their in vivo pathogenicity, to a similar extent (Figure 3). However, it was previously established that the IL-10 production during infection may correlate with the differing filovirus pathogenicity in a particular host species. Exposure of human PBMC to a 17 amino acid (AA) peptide derived from EBOV GP induced IL-10 secretion, in contrast to an analogous peptide from RESV, asymptomatic in humans, which did not [27].

Importantly, we demonstrated that for all three well-studied EBOV strains (Mayinga, Kikwit and Makona), the IL-10 enhancing effect on virus entry occurs not only at concentrations used to alter the macrophage phenotype in vitro, but also at considerably lower levels, which are likely to be present during filovirus infection (Figure $4 \mathrm{~A}-\mathrm{C}$ and Supplemental Table S3). More importantly, the enhancing effect of IL-10 on EBOV VLP fusion was preserved in the presence of pro-inflammatory cytokines (Figures 6A and 6B) shown to be elevated during EBOV infection [3].

The potential impact of macrophage polarization on filovirus pathogenesis is supported by two recent studies. Using a humanized mouse model, Lavender et al. [95] demonstrated that EBOV infection in these animals is associated with a higher frequency of terminally differentiated "M2-like" $\mathrm{CD}_{14}{ }^{+} / \mathrm{CD} 163^{+}$macrophages. MARV, shown to be less pathogenic in this particular animal model, 
caused "a more balanced activation of the M1-like and M2-like macrophage subsets". In the second study, McElroy et al. [96] established that high levels of soluble CD163 and/or increased expression of cell-surface CD163 on tissue macrophages is associated with increased mortality or severity of SUDV or EBOV infection, respectively. It was hypothesized that macrophage activation contributes to the pathogenesis of filovirus infection and an analogy was made with the macrophage activation syndrome and the hemophagocytic lympho-histiocytosis. In support of this model, a reference was made to a previous finding that CD163 may be expressed on both M1 and M2 macrophages [97], but a more detailed characterization of the macrophage phenotype was not performed on the tissue samples obtained from the filovirus infected patients [96]. On the other hand, IL-10, which is associated with increased severity/mortality of filovirus infection, is also a known inducer of CD163 expression $([58,65,68]$ and our own results) and macrophage polarization to the M2c phenotype.

Indeed, in a recent review discussing the role of mononuclear phagocytes in EBOV infection [98], it was speculated that M2 macrophage polarization may enhance EBOV infection. Our study, looking solely at the level of virus entry, has demonstrated that M2c, but not the M2a macrophages, are more prone to fusion with filovirus GP pseudotyped VLP. Whether M2 macrophages, compared to the M1 phenotype, are in general more susceptible to EBOV infection at post-entry steps remains to be determined. We also generated preliminary data, showing that MDM treatment with TGF- $\beta_{1}$, another cytokine linked to the M2c-like phenotype (reviewed in [99-101]), is also capable of enhancing EBOV VLP fusion (Figure 7). However, further studies are needed to determine if the observed enhancing effect of IL-10 and/or TGF- $\beta_{1}$ on VLP entry is mediated by the same factors and to delineate whether TGF- $\beta_{1}$ affects EBOV VLP fusion directly or via potential TGF- $\beta_{1}$ induced IL-10 secretion [102,103].
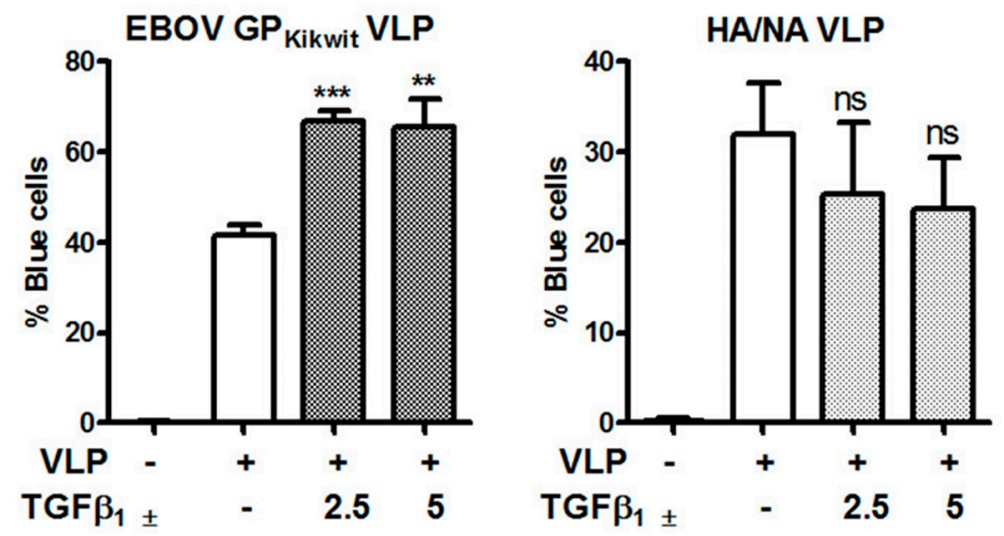

Figure 7. TGF- $\beta 1$ enhances fusion of primary MDM with VLPs pseudotyped with $\mathrm{EBOV}_{\text {Kikwit }}$ GP. MDM were pre-incubated for $72 \mathrm{~h}$ in macrophage medium supplemented with TGF- $\beta 1$ ( $2.5 \mathrm{or} 5 \mathrm{ng} / \mathrm{mL})$ or cytokine resuspension buffer (0.5\% HSA DPBS) prior to infection with $\mathrm{EBOV}_{\text {Kikwit }}$ VLP or HA/NA VLP, respectively. The cells were processed and the VLP entry/fusion was analyzed by Laser Scanning Cytometry, as described in Materials and Methods. No significant difference was observed in the background fluorescence of uninfected TGF- $\beta 1$ or mock treated cells. ${ }^{* *} p \leq 0.01$; ${ }^{* *} p \leq 0.001$; ns $=$ not significant.

Intriguingly, the findings that pre-incubation of primary MDM with IL-10 in combination with several pro-inflammatory cytokines enhances filovirus VLP entry, compared to mock treated controls (Figure 6A,B), imply that the increased ability of macrophages to support filovirus fusion may not be uniquely associated with the typical in vivo M2c phenotype, which is usually induced by adding just IL-10 to the cell culture medium. Whether the same set of molecules is involved in augmenting VLP entry in macrophages exposed to IL-10 alone or IL-10 in combination with pro-inflammatory cytokines is currently being investigated.

It is important to know if changes in IL-10, induced by a concomitant infection, may influence the clinical outcome of EVD. During the 2014-2016 EBOV outbreak, both increased [104,105] or 
decreased [106,107] survival rates were reported in patients co-infected with malaria species. Malaria is known to exert variable effects on IL-10, depending on the severity of infection (lower IL-10 in complicated cases, compared to asymptomatic subjects [108-111]), but cytokine levels, including IL-10, have not been evaluated in the currently published studies on EBOV and malaria co-infection.

In general, IL-10 exerts a pleiotropic effect to ensure a balance between pro- and anti-inflammatory immune responses in the context of a changing host environment during infection. A variety of pathogens have developed different mechanisms to take advantage of the immuno-suppressive effects of IL-10 and certain viruses have the ability to either augment host IL-10 production or encode biologically active IL-10 homologs, as a way to delay virus clearance and/or establish a persistent infection (reviewed in [112-116]. Our results demonstrate that filoviruses may not only employ the general IL-10 effects on the innate and adaptive immune responses [93,117], but may also take advantage of the IL-10 ability to specifically influence macrophage polarization towards a phenotype which favors filovirus fusion and entry, thus emphasizing the need to better understand the complex role of IL-10 in filovirus pathogenicity, as a way to provide new insights for improving treatment and reducing mortality of filovirus infection. Perhaps most importantly, in a setting of limited resources, our findings here suggest a path forward to extend the array of biomarkers of disease progression, to facilitate the adequate identification of patients in greatest need of medical attention.

Supplementary Materials: The following are available online at http://www.mdpi.com/1999-4915/11/10/889/s1, Figure S1: IL-10 has a more pronounced enhancing effect (fold increase) when monocyte-derived macrophages

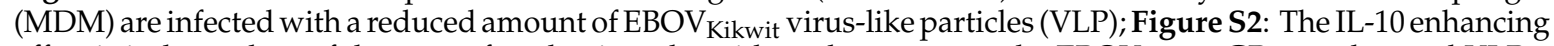

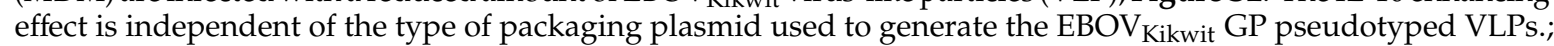
Figure S3: IL-10 enhances fusion of primary MDM with VLPs pseudotyped with envelope glycoproteins from different filovirus species.; Figure S4: Effect of IL-10 on Cathepsin L expression.; Table S1A: Effect of IL-10

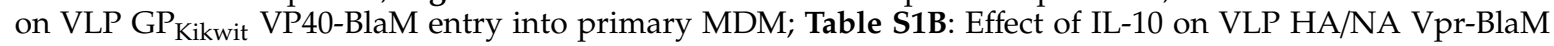
entry into primary MDM; Table S1C: Effect of TNF- $\alpha$ on VLP GPKikwit VP40-BlaM entry into primary MDM; Table S1D: Effect of IL-4 on VLP GPKikwit VP40-BlaM entry into primary MDM; Table S1E: Effect of IL-13 on VLP GPKikwit VP40-BlaM entry into primary MDM; Table S1F: Effect of TNF- $\alpha$ on VLP HA/NA Vpr-BlaM entry into primary MDM; Table S1G: Effect of IL-4 on VLP HA/NA Vpr-BlaM entry into primary MDM; Table S1H: Effect of IL-13 on VLP HA/NA Vpr-BlaM entry into primary MDM; Table S1I: Effect of IL-10 on VLP $\triangle$ mucin GPKikwit VP40-BlaM entry into primary MDM; Table S1J: Effect of IL-10 on VLP GPKikwit Vpr-BlaM entry into primary MDM; Table S2: Significant changes in IL-10-induced gene expression of selected molecules associated with M2c macrophage polarization or EBOV cellular entry.; Table S3: Changes in IL-10 levels observed in survivors and non-survivors during filovirus infection.

Author Contributions: Conceptualization, T.S.S. and K.A.C.; Methodology, T.S.S.; Investigation, T.S.S. A.Z-T. and N.M.; Data curation, T.S.S., A.Z-T. and N.M., Validation, T.S. and K.A.C.; Resources, K.A.C., C.C.B. and K.S.; Writing (original draft preparation), T.S.S.; Writing (review and editing), K.A.C., C.C.B. and K.S.; Supervision, K.A.C.; Funding acquisition, K.A.C. and T.S.S.

Funding: This work was supported in part by the US Food and Drug Administration (FDA) Medical Countermeasures Initiative (MCMi). It was also partially supported by the appointment of Autumn Zack-Taylor and Nicholas Mattson to the Research Participation Program at the Center for Drug Evaluation and Research administered by the Oak Ridge Institute for Science and Education through an interagency agreement between the U.S. Department of Energy and the US FDA.

Acknowledgments: The authors would like to thank Judith White, Andrea Marzi, Carol Weiss, Gary Nabel, Yoshihiro Kawaoka, Lijun Rong and Paul Bieniasz for providing plasmid constructs. The authors would also like to thank David Frucht and Nozomi Sakakibara for the critical reading of the manuscript, Mark Kukuruga, Adove Akue and Howard Mostowski for the technical expertise regarding flow cytometry and William Telford and Ken Conte for their expert assistance with the iCys laser scanning cytometry.

Conflicts of Interest: The authors declare no conflict of interest. The funders had no role in the design of the study; in the collection, analyses, or interpretation of data; in the writing of the manuscript, or in the decision to publish the results. This work represents the views of the authors and does not necessarily reflect those of the Food and Drug Administration, the National Institute of Allergy and Infectious Diseases/National Institutes of Health and/or the Uniformed Services University. 


\section{References}

1. Villinger, F.; Rollin, P.E.; Brar, S.S.; Chikkala, N.F.; Winter, J.; Sundstrom, J.B.; Zaki, S.R.; Swanepoel, R.; Ansari, A.A.; Peters, C.J. Markedly elevated levels of interferon (ifn)-gamma, ifn-alpha, interleukin (il)-2, il-10, and tumor necrosis factor-alpha associated with fatal ebola virus infection. J. Infect. Dis. 1999, 179 (Suppl. 1), S188-S191. [CrossRef] [PubMed]

2. Baize, S.; Leroy, E.M.; Georges, A.J.; Georges-Courbot, M.C.; Capron, M.; Bedjabaga, I.; Lansoud-Soukate, J.; Mavoungou, E. Inflammatory responses in ebola virus-infected patients. Clin. Exp. Immunol. 2002, 128, 163-168. [CrossRef] [PubMed]

3. Ruibal, P.; Oestereich, L.; Ludtke, A.; Becker-Ziaja, B.; Wozniak, D.M.; Kerber, R.; Korva, M.; Cabeza-Cabrerizo, M.; Bore, J.A.; Koundouno, F.R.; et al. Unique human immune signature of ebola virus disease in guinea. Nature 2016, 533, 100-104. [CrossRef] [PubMed]

4. Leroy, E.M.; Baize, S.; Debre, P.; Lansoud-Soukate, J.; Mavoungou, E. Early immune responses accompanying human asymptomatic ebola infections. Clin. Exp. Immunol. 2001, 124, 453-460. [CrossRef] [PubMed]

5. Leroy, E.M.; Baize, S.; Volchkov, V.E.; Fisher-Hoch, S.P.; Georges-Courbot, M.C.; Lansoud-Soukate, J.; Capron, M.; Debre, P.; McCormick, J.B.; Georges, A.J. Human asymptomatic ebola infection and strong inflammatory response. Lancet 2000, 355, 2210-2215. [CrossRef]

6. Kash, J.C.; Walters, K.A.; Kindrachuk, J.; Baxter, D.; Scherler, K.; Janosko, K.B.; Adams, R.D.; Herbert, A.S.; James, R.M.; Stonier, S.W.; et al. Longitudinal peripheral blood transcriptional analysis of a patient with severe ebola virus disease. Sci. Transl. Med. 2017, 9, eaai9321. [CrossRef] [PubMed]

7. Vernet, M.A.; Reynard, S.; Fizet, A.; Schaeffer, J.; Pannetier, D.; Guedj, J.; Rives, M.; Georges, N.; Garcia-Bonnet, N.; Sylla, A.I.; et al. Clinical, virological, and biological parameters associated with outcomes of ebola virus infection in macenta, guinea. JCI Insight 2017, 2, e88864. [CrossRef] [PubMed]

8. McElroy, A.K.; Harmon, J.R.; Flietstra, T.D.; Campbell, S.; Mehta, A.K.; Kraft, C.S.; Lyon, M.G.; Varkey, J.B.; Ribner, B.S.; Kratochvil, C.J.; et al. Kinetic analysis of biomarkers in a cohort of us patients with ebola virus disease. Clin. Infect. Dis. Off. Publ. Infect. Dis. Soc. Am. 2016, 63, 460-467. [CrossRef] [PubMed]

9. Reynard, S.; Journeaux, A.; Gloaguen, E.; Schaeffer, J.; Varet, H.; Pietrosemoli, N.; Mateo, M.; Baillet, N.; Laouenan, C.; Raoul, H.; et al. Immune parameters and outcomes during ebola virus disease. JCI Insight 2019, 4, e125106. [CrossRef]

10. Hutchinson, K.L.; Rollin, P.E. Cytokine and chemokine expression in humans infected with sudan ebola virus. J. Infect. Dis. 2007, 196 (Suppl. 2), S357-S363. [CrossRef]

11. Gupta, M.; MacNeil, A.; Reed, Z.D.; Rollin, P.E.; Spiropoulou, C.F. Serology and cytokine profiles in patients infected with the newly discovered bundibugyo ebolavirus. Virology 2012, 423, 119-124. [CrossRef] [PubMed]

12. Gupta, M.; Mahanty, S.; Ahmed, R.; Rollin, P.E. Monocyte-derived human macrophages and peripheral blood mononuclear cells infected with ebola virus secrete mip-1alpha and tnf-alpha and inhibit poly-ic-induced ifn-alpha in vitro. Virology 2001, 284, 20-25. [CrossRef] [PubMed]

13. Gupta, M.; Goldsmith, C.S.; Metcalfe, M.G.; Spiropoulou, C.F.; Rollin, P.E. Reduced virus replication, proinflammatory cytokine production, and delayed macrophage cell death in human pbmcs infected with the newly discovered bundibugyo ebolavirus relative to zaire ebolavirus. Virology 2010, 402, 203-208. [CrossRef] [PubMed]

14. Stroher, U.; West, E.; Bugany, H.; Klenk, H.D.; Schnittler, H.J.; Feldmann, H. Infection and activation of monocytes by marburg and ebola viruses. J. Virol. 2001, 75, 11025-11033. [CrossRef] [PubMed]

15. Wahl-Jensen, V.; Kurz, S.; Feldmann, F.; Buehler, L.K.; Kindrachuk, J.; DeFilippis, V.; da Silva Correia, J.; Fruh, K.; Kuhn, J.H.; Burton, D.R.; et al. Ebola virion attachment and entry into human macrophages profoundly effects early cellular gene expression. PLoS Negl. Trop. Dis. 2011, 5, e1359. [CrossRef] [PubMed]

16. Warfield, K.L.; Bosio, C.M.; Welcher, B.C.; Deal, E.M.; Mohamadzadeh, M.; Schmaljohn, A.; Aman, M.J.; Bavari, S. Ebola virus-like particles protect from lethal ebola virus infection. Proc. Natl. Acad. Sci. USA 2003, 100, 15889-15894. [CrossRef] [PubMed]

17. Escudero-Perez, B.; Volchkova, V.A.; Dolnik, O.; Lawrence, P.; Volchkov, V.E. Shed gp of ebola virus triggers immune activation and increased vascular permeability. PLoS Pathog. 2014, 10, e1004509. [CrossRef] [PubMed] 
18. Zhao, D.; Han, X.; Zheng, X.; Wang, H.; Yang, Z.; Liu, D.; Han, K.; Liu, J.; Wang, X.; Yang, W.; et al. The myeloid lsectin is a dap12-coupled receptor that is crucial for inflammatory response induced by ebola virus glycoprotein. PLoS Pathog. 2016, 12, e1005487.

19. Bosio, C.M.; Moore, B.D.; Warfield, K.L.; Ruthel, G.; Mohamadzadeh, M.; Aman, M.J.; Bavari, S. Ebola and marburg virus-like particles activate human myeloid dendritic cells. Virology 2004, 326, 280-287. [CrossRef]

20. Ayithan, N.; Bradfute, S.B.; Anthony, S.M.; Stuthman, K.S.; Dye, J.M.; Bavari, S.; Bray, M.; Ozato, K. Ebola virus-like particles stimulate type i interferons and proinflammatory cytokine expression through the toll-like receptor and interferon signaling pathways. J. Interferon Cytokine Res. 2014, 34, 79-89. [CrossRef]

21. Warfield, K.L.; Perkins, J.G.; Swenson, D.L.; Deal, E.M.; Bosio, C.M.; Aman, M.J.; Yokoyama, W.M.; Young, H.A.; Bavari, S. Role of natural killer cells in innate protection against lethal ebola virus infection. J. Exp. Med. 2004, 200, 169-179. [CrossRef] [PubMed]

22. Wahl-Jensen, V.; Kurz, S.K.; Hazelton, P.R.; Schnittler, H.J.; Stroher, U.; Burton, D.R.; Feldmann, H. Role of ebola virus secreted glycoproteins and virus-like particles in activation of human macrophages. J. Virol. 2005, 79, 2413-2419. [CrossRef] [PubMed]

23. Ye, L.; Lin, J.; Sun, Y.; Bennouna, S.; Lo, M.; Wu, Q.; Bu, Z.; Pulendran, B.; Compans, R.W.; Yang, C. Ebola virus-like particles produced in insect cells exhibit dendritic cell stimulating activity and induce neutralizing antibodies. Virology 2006, 351, 260-270. [CrossRef] [PubMed]

24. Okumura, A.; Pitha, P.M.; Yoshimura, A.; Harty, R.N. Interaction between ebola virus glycoprotein and host toll-like receptor 4 leads to induction of proinflammatory cytokines and socs1. J. Virol. 2010, 84, 27-33. [CrossRef] [PubMed]

25. Martinez, O.; Leung, L.W.; Basler, C.F. The role of antigen-presenting cells in filoviral hemorrhagic fever: Gaps in current knowledge. Antivir. Res. 2012, 93, 416-428. [CrossRef] [PubMed]

26. Sobarzo, A.; Eskira, Y.; Herbert, A.S.; Kuehne, A.I.; Stonier, S.W.; Ochayon, D.E.; Fedida-Metula, S.; Balinandi, S.; Kislev, Y.; Tali, N.; et al. Immune memory to sudan virus: Comparison between two separate disease outbreaks. Viruses 2015, 7, 37-51. [CrossRef] [PubMed]

27. Yaddanapudi, K.; Palacios, G.; Towner, J.S.; Chen, I.; Sariol, C.A.; Nichol, S.T.; Lipkin, W.I. Implication of a retrovirus-like glycoprotein peptide in the immunopathogenesis of ebola and marburg viruses. FASEB J. 2006, 20, 2519-2530. [CrossRef] [PubMed]

28. Farooq, F.; Beck, K.; Paolino, K.M.; Phillips, R.; Waters, N.C.; Regules, J.A.; Bergmann-Leitner, E.S. Circulating follicular thelper cells and cytokine profile in humans following vaccination with the rvsv-zebov ebola vaccine. Sci. Rep. 2016, 6, 27944. [CrossRef]

29. Younan, P.; Iampietro, M.; Nishida, A.; Ramanathan, P.; Santos, R.I.; Dutta, M.; Lubaki, N.M.; Koup, R.A.; Katze, M.G.; Bukreyev, A. Ebola virus binding to tim-1 on tymphocytes induces a cytokine storm. mBio 2017, 8, e00845-17. [CrossRef]

30. Younan, P.; Ramanathan, P.; Graber, J.; Gusovsky, F.; Bukreyev, A. The toll-like receptor 4 antagonist eritoran protects mice from lethal filovirus challenge. mBio 2017, 8, e00226-17. [CrossRef]

31. Lai, C.Y.; Strange, D.P.; Wong, T.A.S.; Lehrer, A.T.; Verma, S. Ebola virus glycoprotein induces an innate immune response in vivo via tlr4. Front. Microbiol. 2017, 8, 1571. [CrossRef] [PubMed]

32. McElroy, A.K.; Erickson, B.R.; Flietstra, T.D.; Rollin, P.E.; Nichol, S.T.; Towner, J.S.; Spiropoulou, C.F. Ebola hemorrhagic fever: Novel biomarker correlates of clinical outcome. J. Infect. Dis. 2014, 210, 558-566. [CrossRef] [PubMed]

33. Jiang, T.; Jiang, J.F.; Deng, Y.Q.; Jiang, B.G.; Fan, H.; Han, J.F.; Hu, Y.; Zhuang, D.M.; Kargbo, D.; An, X.P.; et al. Features of ebola virus disease at the late outbreak stage in sierra leone: Clinical, virological, immunological, and evolutionary analyses. J. Infect. Dis. 2017, 215, 1107-1110. [CrossRef] [PubMed]

34. Bradfute, S.B.; Bavari, S. Correlates of immunity to filovirus infection. Viruses 2011, 3, 982-1000. [CrossRef] [PubMed]

35. Wauquier, N.; Becquart, P.; Padilla, C.; Baize, S.; Leroy, E.M. Human fatal zaire ebola virus infection is associated with an aberrant innate immunity and with massive lymphocyte apoptosis. PLoS Negl. Trop. Dis. 2010, 4, e837. [CrossRef] [PubMed]

36. Anthony, S.M.; Bradfute, S.B. Filoviruses: One of these things is (not) like the other. Viruses 2015, 7, 5172-5190. [CrossRef] [PubMed]

37. Wojdasiewicz, P.; Poniatowski, L.A.; Szukiewicz, D. The role of inflammatory and anti-inflammatory cytokines in the pathogenesis of osteoarthritis. Mediat. Inflamm. 2014, 2014, 561459. [CrossRef] 
38. Feldmann, H.; Geisbert, T.W. Ebola haemorrhagic fever. Lancet 2011, 377, 849-862. [CrossRef]

39. Bixler, S.L.; Goff, A.J. The role of cytokines and chemokines in filovirus infection. Viruses 2015, 7, 5489-5507. [CrossRef]

40. Locati, M.; Mantovani, A.; Sica, A. Macrophage activation and polarization as an adaptive component of innate immunity. Adv. Immunol. 2013, 120, 163-184.

41. Martinez, F.O.; Sica, A.; Mantovani, A.; Locati, M. Macrophage activation and polarization. Front. Biosci. J. Virtual Libr. 2008, 13, 453-461. [CrossRef] [PubMed]

42. Mantovani, A.; Sica, A.; Sozzani, S.; Allavena, P.; Vecchi, A.; Locati, M. The chemokine system in diverse forms of macrophage activation and polarization. Trends Immunol. 2004, 25, 677-686. [CrossRef] [PubMed]

43. Xue, J.; Schmidt, S.V.; Sander, J.; Draffehn, A.; Krebs, W.; Quester, I.; De Nardo, D.; Gohel, T.D.; Emde, M.; Schmidleithner, L.; et al. Transcriptome-based network analysis reveals a spectrum model of human macrophage activation. Immunity 2014, 40, 274-288. [CrossRef] [PubMed]

44. Gensel, J.C.; Zhang, B. Macrophage activation and its role in repair and pathology after spinal cord injury. Brain Res. 2015, 1619, 1-11. [CrossRef] [PubMed]

45. Gerrard, T.L.; Jurgensen, C.H.; Fauci, A.S. Differential effect of monoclonal anti-dr antibody on monocytes in antigen- and mitogen-stimulated responses: Mechanism of inhibition and relationship to interleukin 1 secretion. Cell. Immunol. 1983, 82, 394-402. [CrossRef]

46. Lazdins, J.K.; Woods-Cook, K.; Walker, M.; Alteri, E. The lipophilic muramyl peptide mtp-pe is a potent inhibitor of hiv replication in macrophages. AIDS Res. Hum. Retrovir. 1990, 6, 1157-1161. [CrossRef] [PubMed]

47. Broder, C.C.; Kennedy, P.E.; Michaels, F.; Berger, E.A. Expression of foreign genes in cultured human primary macrophages using recombinant vaccinia virus vectors. Gene 1994, 142, 167-174. [CrossRef]

48. Zhao, Z.; Hou, X.; Yin, X.; Li, Y.; Duan, R.; Boyce, B.F.; Yao, Z. Tnf induction of nf-kappab relb enhances rankl-induced osteoclastogenesis by promoting inflammatory macrophage differentiation but also limits it through suppression of nfatc1 expression. PLoS ONE 2015, 10, e0135728.

49. Donlin, L.T.; Jayatilleke, A.; Giannopoulou, E.G.; Kalliolias, G.D.; Ivashkiv, L.B. Modulation of tnf-induced macrophage polarization by synovial fibroblasts. J. Immunol. (Baltim. Md. 1950) 2014, 193, 2373-2383. [CrossRef]

50. Kroner, A.; Greenhalgh, A.D.; Zarruk, J.G.; Passos Dos Santos, R.; Gaestel, M.; David, S. Tnf and increased intracellular iron alter macrophage polarization to a detrimental $\mathrm{m} 1$ phenotype in the injured spinal cord. Neuron 2014, 83, 1098-1116. [CrossRef]

51. Luczo, J.M.; Stambas, J.; Durr, P.A.; Michalski, W.P.; Bingham, J. Molecular pathogenesis of h5 highly pathogenic avian influenza: The role of the haemagglutinin cleavage site motif. Rev. Med. Virol. 2015, 25, 406-430. [CrossRef] [PubMed]

52. Dube, D.; Schornberg, K.L.; Stantchev, T.S.; Bonaparte, M.I.; Delos, S.E.; Bouton, A.H.; Broder, C.C.; White, J.M. Cell adhesion promotes ebola virus envelope glycoprotein-mediated binding and infection. J. Virol. 2008, 82, 7238-7242. [CrossRef] [PubMed]

53. Dube, D.; Brecher, M.B.; Delos, S.E.; Rose, S.C.; Park, E.W.; Schornberg, K.L.; Kuhn, J.H.; White, J.M. The primed ebolavirus glycoprotein (19-kilodalton gp1,2): Sequence and residues critical for host cell binding. J. Virol. 2009, 83, 2883-2891. [CrossRef] [PubMed]

54. Maecker, H.T.; Frey, T.; Nomura, L.E.; Trotter, J. Selecting fluorochrome conjugates for maximum sensitivity. Cytom. Part A J. Int. Soc. Anal. Cytol. 2004, 62, 169-173. [CrossRef] [PubMed]

55. Maecker, H.; Trotter, J. Selecting reagents for multicolor flow cytometry with bd ${ }^{\mathrm{TM}}$ lsr ii and bd facscanto ${ }^{\mathrm{TM}}$ systems. Nat. Methods 2008, 5, A6. [CrossRef]

56. Martinez, O.; Johnson, J.C.; Honko, A.; Yen, B.; Shabman, R.S.; Hensley, L.E.; Olinger, G.G.; Basler, C.F. Ebola virus exploits a monocyte differentiation program to promote its entry. J. Virol. 2013, 87, 3801-3814. [CrossRef] [PubMed]

57. Dutry, I.; Li, J.; Li, P.H.; Bruzzone, R.; Peiris, J.S.M.; Jaume, M.D.A. The effects of macrophage polarity on influenza virus replication and innate immune responses. J. Clin. Cell. Immunol. 2015, 6, 297.

58. Rey-Giraud, F.; Hafner, M.; Ries, C.H. In vitro generation of monocyte-derived macrophages under serum-free conditions improves their tumor promoting functions. PLoS ONE 2012, 7, e42656. [CrossRef] [PubMed] 
59. Montaner, L.J.; da Silva, R.P.; Sun, J.; Sutterwala, S.; Hollinshead, M.; Vaux, D.; Gordon, S. Type 1 and type 2 cytokine regulation of macrophage endocytosis: Differential activation by il-4/il-13 as opposed to ifn-gamma or il-10. J. Immunol. (Baltim. Md. 1950) 1999, 162, 4606-4613.

60. Zizzo, G.; Cohen, P.L. Il-17 stimulates differentiation of human anti-inflammatory macrophages and phagocytosis of apoptotic neutrophils in response to il-10 and glucocorticoids. J. Immunol. (Baltim. Md. 1950) 2013, 190, 5237-5246. [CrossRef] [PubMed]

61. Lopez-Castejon, G.; Baroja-Mazo, A.; Pelegrin, P. Novel macrophage polarization model: From gene expression to identification of new anti-inflammatory molecules. Cell. Mol. Life Sci. CMLS 2011, 68, 3095-3107. [CrossRef] [PubMed]

62. Tedesco, S.; Bolego, C.; Toniolo, A.; Nassi, A.; Fadini, G.P.; Locati, M.; Cignarella, A. Phenotypic activation and pharmacological outcomes of spontaneously differentiated human monocyte-derived macrophages. Immunobiology 2015, 220, 545-554. [CrossRef] [PubMed]

63. Mia, S.; Warnecke, A.; Zhang, X.M.; Malmstrom, V.; Harris, R.A. An optimized protocol for human $\mathrm{m} 2$ macrophages using $\mathrm{m}$-csf and il-4/il-10/tgf-beta yields a dominant immunosuppressive phenotype. Scand. J. Immunol. 2014, 79, 305-314. [CrossRef] [PubMed]

64. Vogel, D.Y.; Glim, J.E.; Stavenuiter, A.W.; Breur, M.; Heijnen, P.; Amor, S.; Dijkstra, C.D.; Beelen, R.H. Human macrophage polarization in vitro: Maturation and activation methods compared. Immunobiology 2014, 219, 695-703. [CrossRef] [PubMed]

65. Ambarus, C.A.; Krausz, S.; van Eijk, M.; Hamann, J.; Radstake, T.R.; Reedquist, K.A.; Tak, P.P.; Baeten, D.L. Systematic validation of specific phenotypic markers for in vitro polarized human macrophages. J. Immunol. Methods 2012, 375, 196-206. [CrossRef] [PubMed]

66. Ogden, C.A.; Pound, J.D.; Batth, B.K.; Owens, S.; Johannessen, I.; Wood, K.; Gregory, C.D. Enhanced apoptotic cell clearance capacity and $\mathrm{b}$ cell survival factor production by il-10-activated macrophages: Implications for burkitt's lymphoma. J. Immunol. (Baltim. Md. 1950) 2005, 174, 3015-3023. [CrossRef]

67. Murray, P.J.; Allen, J.E.; Biswas, S.K.; Fisher, E.A.; Gilroy, D.W.; Goerdt, S.; Gordon, S.; Hamilton, J.A.; Ivashkiv, L.B.; Lawrence, T.; et al. Macrophage activation and polarization: Nomenclature and experimental guidelines. Immunity 2014, 41, 14-20. [CrossRef]

68. Sulahian, T.H.; Hogger, P.; Wahner, A.E.; Wardwell, K.; Goulding, N.J.; Sorg, C.; Droste, A.; Stehling, M.; Wallace, P.K.; Morganelli, P.M.; et al. Human monocytes express cd163, which is upregulated by il-10 and identical to p155. Cytokine 2000, 12, 1312-1321. [CrossRef]

69. Park-Min, K.H.; Antoniv, T.T.; Ivashkiv, L.B. Regulation of macrophage phenotype by long-term exposure to il-10. Immunobiology 2005, 210, 77-86. [CrossRef]

70. Stantchev, T.; Zack-Taylor, A.; Clouse, K.A. Evaluation of Factors Affecting Filovirus Entry into Primary Human Macrophages (Abstract). In Proceedings of the 2014 Medical Counter Measures Initiative Regulatory Science Symposium, Siver Spring, MD, USA, 2-3 June 2014; FDA: Siver Spring, MD, USA, 2014.

71. Rhein, B.A.; Maury, W.J. Ebola virus entry into host cells: Identifying therapeutic strategies. Curr. Clin. Microbiol. Rep. 2015, 2, 115-124. [CrossRef]

72. Dahlmann, F.; Biedenkopf, N.; Babler, A.; Jahnen-Dechent, W.; Karsten, C.B.; Gnirss, K.; Schneider, H.; Wrensch, F.; O'Callaghan, C.A.; Bertram, S.; et al. Analysis of ebola virus entry into macrophages. J. Infect. Dis. 2015, 212 (Suppl. 2), S247-S257. [CrossRef] [PubMed]

73. Nanbo, A.; Kawaoka, Y. The molecular mechanism of externalization of phosphatidylserine on the surface of ebola virus particles. DNA Cell Biol. 2019, 38, 115-120. [CrossRef] [PubMed]

74. Lemke, G.; Rothlin, C.V. Immunobiology of the tam receptors. Nat. Rev. Immunol. 2008, 8, 327-336. [CrossRef] [PubMed]

75. McElroy, A.K.; Erickson, B.R.; Flietstra, T.D.; Rollin, P.E.; Nichol, S.T.; Towner, J.S.; Spiropoulou, C.F. Biomarker correlates of survival in pediatric patients with ebola virus disease. Emerg. Infect. Dis. 2014, 20, 1683-1690. [CrossRef]

76. Marzi, A.; Feldmann, F.; Hanley, P.W.; Scott, D.P.; Gunther, S.; Feldmann, H. Delayed disease progression in cynomolgus macaques infected with ebola virus makona strain. Emerg. Infect. Dis. 2015, 21, 1777-1783. [CrossRef] [PubMed]

77. WHO. World Health Organization Ebola Situation Report; World Health Organization: Geneva, Switzerland, 2016. 
78. Nyakarahuka, L.; Kankya, C.; Krontveit, R.; Mayer, B.; Mwiine, F.N.; Lutwama, J.; Skjerve, E. How severe and prevalent are ebola and marburg viruses? A systematic review and meta-analysis of the case fatality rates and seroprevalence. BMC Infect. Dis. 2016, 16, 708. [CrossRef] [PubMed]

79. Kuhn, J.H.; Dodd, L.E.; Wahl-Jensen, V.; Radoshitzky, S.R.; Bavari, S.; Jahrling, P.B. Evaluation of perceived threat differences posed by filovirus variants. Biosecur. Bioterror. Biodef. Strategy Pract. Sci. 2011, 9, 361-371. [CrossRef]

80. Shears, P.; O’Dempsey, T.J. Ebola virus disease in africa: Epidemiology and nosocomial transmission. J. Hosp. Infect. 2015, 90, 1-9. [CrossRef]

81. Kerber, R.; Krumkamp, R.; Korva, M.; Rieger, T.; Wurr, S.; Duraffour, S.; Oestereich, L.; Gabriel, M.; Sissoko, D.; Anglaret, X.; et al. Kinetics of soluble mediators of the host response in ebola virus disease. J. Infect. Dis. 2018, 218, S496-S503. [CrossRef]

82. Hutchinson, K.L.; Villinger, F.; Miranda, M.E.; Ksiazek, T.G.; Peters, C.J.; Rollin, P.E. Multiplex analysis of cytokines in the blood of cynomolgus macaques naturally infected with ebola virus (reston serotype). J. Med. Virol. 2001, 65, 561-566. [CrossRef]

83. Hensley, L.E.; Young, H.A.; Jahrling, P.B.; Geisbert, T.W. Proinflammatory response during ebola virus infection of primate models: Possible involvement of the tumor necrosis factor receptor superfamily. Immunol. Lett. 2002, 80, 169-179. [CrossRef]

84. Geisbert, T.W.; Hensley, L.E.; Larsen, T.; Young, H.A.; Reed, D.S.; Geisbert, J.B.; Scott, D.P.; Kagan, E.; Jahrling, P.B.; Davis, K.J. Pathogenesis of ebola hemorrhagic fever in cynomolgus macaques: Evidence that dendritic cells are early and sustained targets of infection. Am. J. Pathol. 2003, 163, 2347-2370. [CrossRef]

85. Rubins, K.H.; Hensley, L.E.; Wahl-Jensen, V.; Daddario DiCaprio, K.M.; Young, H.A.; Reed, D.S.; Jahrling, P.B.; Brown, P.O.; Relman, D.A.; Geisbert, T.W. The temporal program of peripheral blood gene expression in the response of nonhuman primates to ebola hemorrhagic fever. Genome Biol. 2007, 8, R174. [CrossRef] [PubMed]

86. Geisbert, T.W.; Daddario-DiCaprio, K.M.; Geisbert, J.B.; Young, H.A.; Formenty, P.; Fritz, E.A.; Larsen, T.; Hensley, L.E. Marburg virus angola infection of rhesus macaques: Pathogenesis and treatment with recombinant nematode anticoagulant protein c2. J. Infect. Dis. 2007, 196 (Suppl. 2), S372-S381. [CrossRef] [PubMed]

87. Connor, J.H.; Yen, J.; Caballero, I.S.; Garamszegi, S.; Malhotra, S.; Lin, K.; Hensley, L.; Goff, A.J. Transcriptional profiling of the immune response to marburg virus infection. J. Virol. 2015, 89, 9865-9874. [CrossRef]

88. Marsh, G.A.; Haining, J.; Robinson, R.; Foord, A.; Yamada, M.; Barr, J.A.; Payne, J.; White, J.; Yu, M.; Bingham, J.; et al. Ebola reston virus infection of pigs: Clinical significance and transmission potential. J. Infect. Dis. 2011, 204 (Suppl. 3), S804-S809. [CrossRef] [PubMed]

89. Barrette, R.W.; Metwally, S.A.; Rowland, J.M.; Xu, L.; Zaki, S.R.; Nichol, S.T.; Rollin, P.E.; Towner, J.S.; Shieh, W.J.; Batten, B.; et al. Discovery of swine as a host for the reston ebolavirus. Science 2009, 325, 204-206. [CrossRef]

90. Nfon, C.K.; Leung, A.; Smith, G.; Embury-Hyatt, C.; Kobinger, G.; Weingartl, H.M. Immunopathogenesis of severe acute respiratory disease in zaire ebolavirus-infected pigs. PLoS ONE 2013, 8, e61904. [CrossRef]

91. Kobinger, G.P.; Leung, A.; Neufeld, J.; Richardson, J.S.; Falzarano, D.; Smith, G.; Tierney, K.; Patel, A.; Weingartl, H.M. Replication, pathogenicity, shedding, and transmission of zaire ebolavirus in pigs. J. Infect. Dis. 2011, 204, 200-208. [CrossRef]

92. Bird, B.H.; Spengler, J.R.; Chakrabarti, A.K.; Khristova, M.L.; Sealy, T.K.; Coleman-McCray, J.D.; Martin, B.E.; Dodd, K.A.; Goldsmith, C.S.; Sanders, J.; et al. Humanized mouse model of ebola virus disease mimics the immune responses in human disease. J. Infect. Dis. 2016, 213, 703-711. [CrossRef]

93. Panchal, R.G.; Mourich, D.V.; Bradfute, S.; Hauck, L.L.; Warfield, K.L.; Iversen, P.L.; Bavari, S. Induced il-10 splice altering approach to antiviral drug discovery. Nucleic Acid Ther. 2014, 24, 179-185. [CrossRef] [PubMed]

94. Martyushev, A.; Nakaoka, S.; Sato, K.; Noda, T.; Iwami, S. Modelling ebola virus dynamics: Implications for therapy. Antivir. Res. 2016, 135, 62-73. [CrossRef] [PubMed]

95. Lavender, K.J.; Williamson, B.N.; Saturday, G.; Martellaro, C.; Griffin, A.; Hasenkrug, K.J.; Feldmann, H.; Prescott, J. Pathogenicity of ebola and marburg viruses is associated with differential activation of the myeloid compartment in humanized triple knockout-bone marrow, liver, and thymus mice. J. Infect. Dis. 2018, 218, S409-S417. [CrossRef] [PubMed] 
96. McElroy, A.K.; Shrivastava-Ranjan, P.; Harmon, J.R.; Martines, R.B.; Silva-Flannery, L.; Flietstra, T.D.; Kraft, C.S.; Mehta, A.K.; Lyon, G.M.; Varkey, J.B.; et al. Macrophage activation marker soluble cd163 associated with fatal and severe ebola virus disease in humans(1). Emerg. Infect. Dis. 2019, 25, 290-298. [CrossRef] [PubMed]

97. Barros, M.H.; Hauck, F.; Dreyer, J.H.; Kempkes, B.; Niedobitek, G. Macrophage polarisation: An immunohistochemical approach for identifying $\mathrm{m} 1$ and $\mathrm{m} 2$ macrophages. PLoS ONE 2013, 8, e80908. [CrossRef] [PubMed]

98. Rogers, K.J.; Maury, W. The role of mononuclear phagocytes in ebola virus infection. J. Leukoc. Biol. 2018, 104, 717-727. [CrossRef] [PubMed]

99. Shapouri-Moghaddam, A.; Mohammadian, S.; Vazini, H.; Taghadosi, M.; Esmaeili, S.A.; Mardani, F.; Seifi, B.; Mohammadi, A.; Afshari, J.T.; Sahebkar, A. Macrophage plasticity, polarization, and function in health and disease. J. Cell. Physiol. 2018, 233, 6425-6440. [CrossRef] [PubMed]

100. Roszer, T. Understanding the mysterious $\mathrm{m} 2$ macrophage through activation markers and effector mechanisms. Mediat. Inflamm. 2015, 2015, 816460. [CrossRef]

101. Ivashkiv, L.B. Epigenetic regulation of macrophage polarization and function. Trends Immunol. 2013, 34, 216-223. [CrossRef] [PubMed]

102. Maeda, H.; Kuwahara, H.; Ichimura, Y.; Ohtsuki, M.; Kurakata, S.; Shiraishi, A. Tgf-beta enhances macrophage ability to produce il-10 in normal and tumor-bearing mice. J. Immunol. (Baltim. Md. 1950) 1995, 155, 4926-4932.

103. Zhang, F.; Wang, H.; Wang, X.; Jiang, G.; Liu, H.; Zhang, G.; Wang, H.; Fang, R.; Bu, X.; Cai, S.; et al. Tgf-beta induces $\mathrm{m} 2$-like macrophage polarization via snail-mediated suppression of a pro-inflammatory phenotype. Oncotarget 2016, 7, 52294-52306. [PubMed]

104. Rosenke, K.; Adjemian, J.; Munster, V.J.; Marzi, A.; Falzarano, D.; Onyango, C.O.; Ochieng, M.; Juma, B.; Fischer, R.J.; Prescott, J.B.; et al. Plasmodium parasitemia associated with increased survival in ebola virus-infected patients. Clin. Infect. Dis. Off. Publ. Infect. Dis. Soc. Am. 2016, 63, 1026-1033. [CrossRef] [PubMed]

105. Drancourt, M.; Raoult, D. Malaria therapy for ebola virus infection. Clin. Infect. Dis. Off. Publ. Infect. Dis. Soc. Am. 2017, 64, 696-697. [CrossRef] [PubMed]

106. Kerber, R.; Krumkamp, R.; Diallo, B.; Jaeger, A.; Rudolf, M.; Lanini, S.; Bore, J.A.; Koundouno, F.R.; Becker-Ziaja, B.; Fleischmann, E.; et al. Analysis of diagnostic findings from the european mobile laboratory in gueckedou, guinea, march 2014 through march 2015. J. Infect. Dis. 2016, 214, S250-S257. [CrossRef] [PubMed]

107. Waxman, M.; Aluisio, A.R.; Rege, S.; Levine, A.C. Characteristics and survival of patients with ebola virus infection, malaria, or both in sierra leone: A retrospective cohort study. Lancet Infect. Dis. 2017, 17, 654-660. [CrossRef]

108. Mendonca, V.R.; Barral-Netto, M. Immunoregulation in human malaria: The challenge of understanding asymptomatic infection. Memorias do Instituto Oswaldo Cruz 2015, 110, 945-955. [CrossRef]

109. Boeuf, P.S.; Loizon, S.; Awandare, G.A.; Tetteh, J.K.; Addae, M.M.; Adjei, G.O.; Goka, B.; Kurtzhals, J.A.; Puijalon, O.; Hviid, L.; et al. Insights into deregulated tnf and il-10 production in malaria: Implications for understanding severe malarial anaemia. Malar. J. 2012, 11, 253. [CrossRef]

110. Mahanta, A.; Kar, S.K.; Kakati, S.; Baruah, S. Heightened inflammation in severe malaria is associated with decreased il-10 expression levels and neutrophils. Innate Immun. 2015, 21, 546-552. [CrossRef]

111. Mahanta, A.; Baruah, S. Lower expression of gata3 and t-bet correlates with downregulated il-10 in severe falciparum malaria. Clin. Transl. Immunol. 2015, 4, e49. [CrossRef]

112. Ng, C.T.; Oldstone, M.B. Il-10: Achieving balance during persistent viral infection. Curr. Top. Microbiol. Immunol. 2014, 380, 129-144.

113. Redpath, S.; Ghazal, P.; Gascoigne, N.R. Hijacking and exploitation of il-10 by intracellular pathogens. Trends Microbiol. 2001, 9, 86-92. [CrossRef]

114. Mingomataj, E.C.; Bakiri, A.H. Regulator versus effector paradigm: Interleukin-10 as indicator of the switching response. Clin. Rev. Allergy Immunol. 2016, 50, 97-113. [CrossRef] [PubMed]

115. Duell, B.L.; Tan, C.K.; Carey, A.J.; Wu, F.; Cripps, A.W.; Ulett, G.C. Recent insights into microbial triggers of interleukin-10 production in the host and the impact on infectious disease pathogenesis. FEMS Immunol. Med. Microbiol. 2012, 64, 295-313. [CrossRef] [PubMed] 
116. Carey, A.J.; Tan, C.K.; Ulett, G.C. Infection-induced il-10 and jak-stat: A review of the molecular circuitry controlling immune hyperactivity in response to pathogenic microbes. Jak-Stat 2012, 1, 159-167. [CrossRef] [PubMed]

117. Mohamadzadeh, M. Potential factors induced by filoviruses that lead to immune supression. Curr. Mol. Med. 2009, 9, 174-185. [CrossRef] [PubMed] article distributed under the terms and conditions of the Creative Commons Attribution (CC BY) license (http://creativecommons.org/licenses/by/4.0/). 